\title{
Global Prosperity
}

\section{International S'ientifilic e-Jouripnal}

Volume Ilssue I 
Global Prosperity is an academic peerreviewed open-access e-journal. http://gprosperity.org/

\section{Editorial Board Chairman (Legal and} Technical Sciences):

L. Sopilnyk, D.Sc. (Law), D.Sc. (Technical Sciences), Professor (Ukraine) chairmanLS@gprosperity.org

\section{Editorial Board Chairman (Social} Sciences):

L. Yankovska, DSc, Professor (Ukraine) chairmanLY@gprosperity.org

Editor-in-Chief:

Koshovyi, B., PhD (Ukraine) editor@gprosperity.org

Editorial Board (link)

Founder:

Lviv University of Business and Law (Ukraine)

Kulparkivska, 99, 79021, Lviv http://www.lubp.com.ua business law@ukr.net

Publisher:

Oktan Print (Czech Republic)

5. května 1323/9, Praha 4, 14000. https://www.oktanprint.cz/ oktanprint@email.cz

All journal content is licensed under a Creative Commons BY 4.0 International license

Type of publication: electronic

\section{Country of publication:}

Czech Republic

\section{Global Prosperity}

\section{Volume 1 Issue 1}

2021

Kosiuta, M., Sopilnyk, L., Denys, S., Sopilnyk, R., \& Zayats R. Administrative and legal aspects of the activity of the High anti-corruption court and other anticorruption bodies of Ukraine in the context of europeanization

Bordun, 0. Theory of judicial security 23

Yankovska, L. Management of socioeconomic systems in Ukraine: European integration paradigm 31

Sopilnyk, R., \& Semchuk, Y. Problems and prospects of Ukrainian Advocacy development: Euro-integration discourse 37

Yevstakhevych, A., \& Von-Nahy I. K. Prerequisites for the development of a clear social responsibility concept. 43 


\title{
ADMINISTRATIVE AND LEGAL ASPECTS OF THE ACTIVITY OF THE HIGH ANTI-CORRUPTION COURT AND OTHER ANTI-CORRUPTION BODIES OF UKRAINE IN THE CONTEXT OF EUROPEANIZATION
}

\author{
Mykhailo Kosiuta ${ }^{1}$, Lyubomyr Sopilnyk ${ }^{2}$, Solomiya Denys ${ }^{3}$, Rostyslav Sopilnyk ${ }^{4}$, Roman Zayats ${ }^{5}$
}

Received: 2021-02-14

Accepted: 2021-03-25

DOI: http://doi.org/10.46489/gpj.2021-1-1-1

Abstract. The establishment of the High Anti-Corruption Court in Ukraine was a radical step for Ukraine in the fight against corruption. This fact has led to many discussions and debates in scientific circles. The purpose of the article is to administrative and legal characteristics of the legal status of the High Anti-Corruption Court and other Anti-Corruption Bodies of Ukraine and prospects it's activity in the context of Europeanization. The chosen methodology helped to identify the historical origins of corruption; to outline the main features and establish the concept of "corruption"; to analyze the experience of European countries in establishing a system of anti-corruption bodies; to make proposals for reforming the current system of anti-corruption bodies of Ukraine in the context of Europeanization of administrative law. We believe that a key point in the process of improving the effectiveness of the fight against corruption in Ukraine is the need to implement the experience of European countries also in terms of informing and training civil servants professional ethics, awareness and legal culture. The high authority of anti-corruption bodies, as evidenced by the analyzed practice of EU countries (including Denmark), determines the effectiveness of the fight against corruption. Such a system of anti-corruption institutions will help to clearly establish powers, avoid conflicts of interest and bureaucratic schemes, increase the targeted use of budget funds, facilitate citizens' access to relevant bodies with complaints about corruption offenses, and eliminate the privileged status of corrupt officials in the administration of justice.

Keywords: corruption, historical origins, anti-corruption bodies, international experience, anti-corruption bodies of Ukraine

\footnotetext{
${ }^{1}$ Mykhailo Kosiuta, D.Sc. (Law), Professor, Professor of Department of Organization of Judicial, Law Enforcement Agencies and the Bar of National University "Odesa Law Academy”, 23 Fontanskaya road Str., Odesa, 65009, Ukraine, kosytamv@gmail.com, ORCID: https://orcid.org/0000-0001-8021-0873

${ }^{2}$ Lyubomyr Sopilnyk, D.Sc. (Law), D.Sc. (Engineering), Professor, Professor of the Department of Administrative Law and Process, Financial and Information Law of Lviv University of Business and Law, 99 Kulparkivska Str., Lviv, 79021, Ukraine, sopilnyk01@gmail.com, ORCID: http://orcid.org/0000-0001-6581-7255

3 Solomiya Denys, PhD (Law), Lecturer, Ivan Franko National Univetsity of Lviv, 19 Sichovykh Striltsiv Str., Lviv, 79007, Ukraine, solomiyal11201@gmail.com, ORCID: https://orcid.org/0000-0001-6079-2300

${ }^{4}$ Rostyslav Sopilnyk, D.Sc. (Law), Professor, Professor of the Department of Judiciary, Prosecution and Advocacy of Lviv University of Business and Law, 99 Kulparkivska Str., Lviv, 79021, Ukraine, rostyslav.sopilnyk@ukr.net, ORCID: https://orcid.org/0000-0001-9942-6682

5 Roman Zayats, D.Sc. (Law), Professor, Professor of the Department of Administrative Law and Process, Financial and Information Law of Lviv University of Business and Law, 99 Kulparkivska Str., Lviv, 79021, Ukraine, roman.zayats@ukr.net, ORCID: http://orcid.org/0000-0002-4726-6362
} 


\section{INTRODUCTION}

The establishment of the High AntiCorruption Court in Ukraine was a radical step for Ukraine in the fight against corruption. This fact has led to many discussions and debates in scientific circles. Today, the questions are: "Whether such a step was justified? Whether the system of existing anti-corruption bodies is effective?" This phenomenon causes significant damage to public interests, provided it is widespread. Unfortunately, today there is a tendency to increase the level of corruption in Ukraine. This fact negatively affects the economic processes in the country, slows down the path to membership in the European Union, and generally undermines the basic principles of the rule of law. Ukraine's anti-corruption system has undergone significant changes over the past six years. However, there are significant shortcomings of an organizational and legal nature in the activities of anti-corruption bodies, based on the inconsistency of powers due to their excessive number and inadequate legal support. These problems lead to the spread of corruption and a low level of public confidence in Ukraine's anti-corruption bodies. That is why there is an urgent need to reform the current system of anticorruption bodies, which justifies the relevance of the chosen topic. The experience of European countries with low levels of corruption and those that have taken significant steps to reduce them is a good example for Ukraine. In our opinion, in the context of Europeanization of administrative law, it is expedient to implement the achievements of European countries in the current legislation of Ukraine and to take into account the historical, political, and cultural development of Ukrainian society.

Therefore, the purpose of the article is to administrative and legal characteristics of the legal status of the High AntiCorruption Court and other AntiCorruption Bodies of Ukraine and prospects it's activity in the context of Europeanization.

\section{METHODOLOGY}

In the process of research on this topic were used general scientific research methods, which include: methods of empirical research, theoretical knowledge and general methods, in particular:

- abstraction - used in the study of the High Anti-Corruption Court and other bodies of current anti-corruption system of Ukraine and foreign countries in order to further develop proposals for its reform;

- analysis - used in the study of the conceptual apparatus of corruption, historical aspects of corruption as a social phenomenon, anti-corruption bodies and the specifics of legal regulation of the system and activities of anti-corruption bodies in current legislation of Ukraine and European countries;

- deduction - used in the study of theoretical aspects of corruption of the High Anti-Corruption Court and other bodies of current anti-corruption system of Ukraine and foreign countries;

- induction - used to clarify the shortcomings of the High Anti-Corruption Court and other bodies of current anticorruption system of Ukraine and foreign countries, which allowed to draw conclusions about the state of the current system of anti-corruption bodies in Ukraine;

- historical method - in determining the origins and formation of corruption as a negative social phenomenon;

- logical method - used in theoretical form for the purpose of chronological presentation of historical aspects of the emergence and spread of corruption;

- forecasting - on the basis of available data the own position concerning the further prospects of development of system of anti-corruption bodies in the context of Europeanization of administrative law is described; 
- synthesis - used in generalizing the signs of corruption in order to derive the concept of "corruption", as well as in clarifying the legal status of anti-corruption bodies in the context of forming them into an effective system;

- generalization - used in the study of the experience of some European countries regarding the current systems of anti-corruption bodies in order to further apply certain aspects of reforming the system of anti-corruption bodies in Ukraine.

The chosen methodology helped: to identify the historical origins of corruption; to outline the main features and establish the concept of "corruption"; to analyze the experience of European countries in establishing a system of anti-corruption bodies; to make proposals for reforming the current system of anti-corruption bodies of Ukraine in the context of Europeanization of administrative law.

\section{RESULTS}

The definition of "Europeanization" was proposed by R. Ladrech. Europeanization, according to the scientist, is "a gradual process that reorients the direction and forms of (domestic) policies to the level at which European political and economic dynamics grow into part of the organizational (constructive) logic of national policy and its formation" (Betsa, 2009, p. 36; Mikhel, 2011, p. 22).

Y. Yurinets considers the Europeanization of administrative law as the assimilation of the European style of legal thinking, law-making practice, and law enforcement in the activities of public administration (Yurinets, 2015, p. 80).

Ukraine is a member state of the Council of Europe (hereinafter - the CoE). Accordingly, the decisions of the Council of Europe and the decisions of the European Court of Human Rights are binding on the territory of Ukraine. Adherence to these decisions of the Council of Europe, the European Court of Human Rights, and following other recommendations of the
Council of Europe brings Ukraine closer to EU standards (Yurinets, 2015, p. 82).

In 2014, then-US Vice President Joe Biden paid a visit to Kyiv. In his speech, the politician noted that corruption is a "cancer" of Ukrainian society (Wilkinson, 2019).

Allegations of the absolute eradication of this phenomenon in the state seem questionable. The main task of the government, in our opinion, is to minimize corruption. One of the key elements in the fight against corruption is the creation of an effective system of anti-corruption bodies and a regulatory framework for their proper interaction.

E. Dimant and T. Schulte note the important role of establishing an effective system of anti-corruption institutions. Scholars argue that institutions play an important role both in providing a sound legal environment and in promoting the business of individual companies (Dimant, 2016, p. 68). Institutions that operate inefficiently lead to a loss of public confidence, which is why they play a particularly important role in combating corruption (Dreher, 2004).

In order to analyze this issue in detail, first of all, we propose to analyze the legal nature and historical origins of corruption.

\section{The concept of "corruption"}

The definition of "corruption" is formalized in the current legislation of Ukraine. The legislator in Article 1 of the Law of Ukraine "On Prevention of Corruption" defines the term "corruption" as the use of a person specified in part one of Article 3 of this Law (persons authorized to perform state or local government functions; persons who for the purposes of this Law are equated to persons authorized to perform the functions of the state or local self-government, persons who permanently or temporarily hold positions related to the performance of organizational or administrative duties, or specially authorized to perform such duties 
in legal entities of private law regardless of the organizational and legal form, as well as other persons who are not officials and who perform work or provide services in accordance with the contract with the enterprise, institution, organization - in cases provided by this Law, candidates for President of Ukraine and candidates for People's Deputies of Ukraine, registered in the manner prescribed by law, provided to her by officials powers or related opportunities for the purpose of obtaining an improper benefit or accepting such benefit or accepting a promise/offer of such benefit for oneself or others or, respectively, a promise/offer or providing an improper benefit to a person referred to in part 1 of Article 3 of this Law, or at its request, to other natural or legal persons in order to persuade this person to illegally use the official powers granted to him or her.

There is no consensus among scholars on the nature of corruption. The term "corruption" comes from the Latin word "corumpere", which literally translates as "damage", "abuse" (Friedrich, 1967).

Most foreign scholars conclude that the very etymology of the concept of "corruption" is quite ambiguous.

Machiavelli defined the term "corruption" as a process that "gradually destroyed the virtue (virtu) of citizens" (Heidenheimer, 2017).

According to the famous GermanAmerican political scientist K. Friedrich, "any attempt to analyze the concept of corruption will contradict the fact that in English and other languages the word "corruption" has historically had completely different meanings and connotations" (Friedrich, 1967).

There are 9 meanings of the term "Corruption" in the Oxford English Dictionary, of which only one can be used in a political context: "corruption is a breach or non-performance of public duties through bribery or other forms of bribery; the use or existence of corrupt practices, especially in the state, corporations, etc." (The Oxford English Dictionary).

J. Bryce, an English academic, lawyer, and diplomat, defined corruption in three senses, namely: bribery of civil servants (cash payment); another type of bribery of civil servants; as speculation with documents; as speculation for the benefit of candidates. The main element of corruption is bribery of civil servants (Bryce, 1921, pp. 149-150).

Also, there is a definition of corruption as behavior that deviates from the normal performance of duties by a public official to obtain "private (family or clan), material or status benefits" (Nye, 1967). This statement is accurate because corruption has harms all types of public life.

Ye. Nevmerzhytskyi considers corruption as a socio-political phenomenon. The scholar notes that the peculiarity of corruption is that officials of the legislative, executive, judicial branches of government, public associations, institutions, economic management organizations of all forms of ownership of their official position to obtain material values (Nevmerzhytskyi, 2008, p. 44). The social component, in our opinion, is an unconditional sign of corruption, as this phenomenon can be formed only in society.

0. Akimov considers corruption through the prism of psychology. He argues that corruption is not only a social but also a psychological and moral phenomenon. Because it does not exist separately from people, in particular their behavior or activities. "Corruption is a way of thinking that determines the way of life" (Akimov, 2014 , p. 181). In conclusion, the scientist cites the definition of corruption as a complex socio-psychological phenomenon that arises as a result of the implementation of power relations by authorized persons, who, in turn, illegally use power to meet personal needs. We agree with the position of the scientist on the presence of a psychological aspect in 
corruption, as a man as a biological being is primarily guided by self-interest.

Thus, in our opinion, the term "corruption" should be understood as a complex negative social phenomenon, which is due to historical and political processes in the state and psychological features of human thinking, which manifests itself in improper performance or non-performance of public administration to satisfy personal interests.

\section{Historical origins of corruption}

Such a social phenomenon as corruption has existed since ancient times, and the key goal of public authorities is to minimize this phenomenon. We propose to address the historical origins of corruption. It should be noted that the manifestations of corruption were first documented in the V-IV century BC. It was Aristotle who defined the concept of "corruption" as tyranny or an incorrect, corrupt form of monarchy.

During the existence of the Roman Empire, Mark Cicero blamed the governor of Sicily. He delivered a speech in the Roman Senate, which mentioned the extortion of art by the governor of Sicily from the people of Sicily (Gasparov, 1991, p. 29).

Later, Gaius Julius Caesar introduced punishment for bribing high-ranking officials. In particular, voter bribery in ancient Rome was quite common. Therefore, these actions were prohibited.

In the 5th century BC, Confucius noted that officials' concern for their families could lead to abuse of office (Soloviov, 2011).

The Middle Ages are characterized by the intensification of ecclesiastical law. Bishops were characterized as "hunters of money, not souls" (Soloviov, 2011).

In modern times, bribery of state justice has intensified with the help of influential relatives, famous people, etc. By using pressure or bribing high-ranking officials, they managed to hide the crimes they committed (Soloviov, 2011).

The first scientific studies of corruption in the science of political science began in the 60 s of the twentieth century. However, the term "political corruption" appeared in the late 19th century, and there is still no consensus on the term.

\section{The system of anti-corruption bodies of Ukraine}

As of today, Ukraine has reformed the current legislation in the context of Europeanization of Ukrainian legislation, in particular administrative law.

The problem of corruption has gained worldwide notoriety. World institutions are trying to actively oppose it. In the context of European integration processes, Ukraine is on a difficult path to counteract this phenomenon, as political and economic problems have a significant impact on the formation of Ukraine as a country with "European values" and the implementation of these values in the legal sphere.

According to Transparency International, Ukraine's Corruption Perceptions Index is 30 out of a possible 100. According to these data, Ukraine has returned to the level of 2017 and now occupies 126th place out of 180 countries. Next to Ukraine in the ranking is Kyrgyzstan, Azerbaijan, and Djibouti. SRI leaders have not changed significantly. In the first place - New Zealand and Denmark, who scored 87 points each (Transparency International Ukraine, 2019).

The structure of an anti-corruption bodies of Ukraine includes: Verkhovna Rada of Ukraine (hereinafter referred to as the VRU); Cabinet of Ministers of Ukraine (hereinafter referred to as the CMU); Ministry of Justice of Ukraine (hereinafter referred to as the MJU); National Anticorruption Policy Council (hereinafter referred to as the NAPC); The National Agency on Corruption Prevention 
(hereinafter referred to as the NACP); National Anti-Corruption Bureau of Ukraine (hereinafter referred to as the NABU); Prosecutor's Office of Ukraine (hereinafter referred to as the PPO); Specialized Anti-Corruption Prosecutor's Office (hereinafter referred to as the SAP); National Police of Ukraine (hereinafter referred to as the NPU); State Bureau of Investigations (hereinafter referred to as the SBI); Courts of General Jurisdiction; High Anti-Corruption Court (hereinafter referred to as the HAC); Security Service of Ukraine (hereinafter referred to as the SSU); Asset Recovery and Management Agency (hereinafter referred to as the ARMA).

Verkhovna Rada of Ukraine, as the highest legislative body of Ukraine, adopts the Anti-Corruption Strategy and holds parliamentary hearings. The Committee on Anti-Corruption Policy carries out anticorruption examination of draft laws.

Cabinet of Ministers of Ukraine, as the highest executive body of Ukraine, approves the State Program for the Implementation of the Anti-Corruption Strategy.

Ministry of Justice of Ukraine carries out anti-corruption expertise of normative legal acts (with except laws, the examination of which is conducted by the Committee on Anti-Corruption Policy).

National Anticorruption Policy Council is an advisory body under the President of Ukraine, which provides recommendations on the development of anti-corruption policy in Ukraine. The National Council is headed by a chairman appointed by the President of Ukraine.

The Executive Secretary of the National Council is the Deputy Head of the Administration of the President of Ukraine, who is in charge of combating corruption.

The main tasks of the NAPC are: preparation and submission to the President of Ukraine of proposals on defining and updating the improvement of the anti-corruption strategy; implementation of a systematic analysis of the state of prevention and counteraction to corruption in Ukraine, the effectiveness of the implementation of anti-corruption strategy, measures taken to prevent and combat corruption; preparation and submission to the President of Ukraine of agreed proposals for improving coordination and interaction between entities that implement measures in the field of preventing and combating corruption; assessment of the state and promotion of the recommendations of The Group of States against Corruption (GRECO), the Organization for Economic Cooperation and Development (OECD), other leading international organizations to prevent and combat corruption, increase the effectiveness of Ukraine's international cooperation in this area; assistance in scientific and methodological support on preventing and combating corruption.

The National Council, in accordance with its main tasks: carries out a comprehensive assessment of the situation and trends in the field of preventing and combating corruption in Ukraine, analyzes national anti-corruption legislation and measures for its implementation; monitors and analyzes the effectiveness of the implementation of the anti-corruption strategy, makes proposals to improve the interaction of bodies responsible for its implementation; participates in the preparation for submission by the President of Ukraine to the VRU of draft laws in the field of prevention and counteraction to corruption; prepares proposals for bills, draft other regulations in the field of preventing and combating corruption; participates in the preparation of messages of the President of Ukraine to the people, annual and extraordinary messages to the VRU on the internal and external position of Ukraine in the implementation of anti-corruption policy; organizes the study of public opinion on issues considered by the National Council, provides coverage in the media of the results of its work; promotes scientific and 
methodological support on the prevention and combating of corruption, conducting analytical research, development of methodological recommendations in this area; prepares proposals to increase the effectiveness of Ukraine's international cooperation in the field of preventing and combating corruption (On the National Council for Anti-Corruption Policy: Decree of the President of Ukraine, 2014).

The National Anti-Corruption Bureau of Ukraine (NABU) is a state law enforcement body that detects, terminates, investigates and discloses corruption offenses, prevents the commission of new ones. The National Bureau is a legal entity governed by public law. NABU was established on the basis of the Law "On the National Anti-Corruption Bureau of Ukraine" of October 14, 2014.

The task of the NABU is to combat criminal corruption offenses committed by high-ranking officials (for example, the President of Ukraine, MPs, the Prime Minister of Ukraine, ministers, prosecutors, judges, etc.) authorized to perform state or local government functions. threat to national security (On the National AntiCorruption Bureau of Ukraine: Law of Ukraine, 2014).

The National Agency on Corruption Prevention (NACP) is the central executive body of Ukraine with a special status, which ensures the formation and implementation of state anti-corruption policy, formulates rules to prevent corruption and increase public sector transparency. The NACP is a collegial body with five members.

Prosecutor's Office of Ukraine (PPO) provides procedural support, in particular the management and support of the state prosecution in court in courts of general jurisdiction for the consideration of cases that fall under the jurisdiction of NABU, SBI, SSU.

The Specialized Anti-Corruption Prosecutor's Office (SAP) is an independent unit of the Office of the Prosecutor General that provides procedural guidance and support to the prosecution of the WACS in proceedings under NABU's jurisdiction.

State Bureau of Investigations (hereinafter referred to as the SBI) is a law enforcement agency that investigates certain corruption offenses, mostly committed by law enforcement or organized groups.

The National Police of Ukraine (NPU) investigates corruption offenses that are not within the jurisdiction of NABU or the DBR or corruption administrative offenses.

High Anti-Corruption Court (HAC). On June 7, 2018, the VRU adopted the Law "On the High Anti-Corruption Court" (On the High Anti-Corruption Court: Law of Ukraine, 2018). The creation of this institution of the judiciary has raised a number of controversial issues among politicians and scholars. The main reasons for the establishment of the HAC were the requirements of the European community for its establishment and the need to increase the efficiency of the judiciary in dealing with categories of cases under the jurisdiction of NABU-SAP.

As noted above, NGOs, officials of the European Union and the United States, the Venice Commission, Transparency International, and others have insisted on the establishment of an independent body of anti-corruption courts in Ukraine. In addition, the establishment of an independent anti-corruption court is one of the requirements of the International Monetary Fund. The Director of the NABU of Ukraine actively promotes the need to create a separate anti-corruption court, explaining the inefficiency of the newly formed anti-corruption bodies by the lack of an independent judiciary that would quickly and independently review materials submitted to it.

According to Article 125 of the Constitution of Ukraine, the judiciary in Ukraine is built on the principles of territoriality and specialization, and the 
creation of emergency and special courts is not allowed.

The competence of the HAC includes the consideration of cases opened by NABU or SAP against high-ranking officials for committing corruption offenses. The WACS Judicial Chamber has 27 judges. Cases are heard collectively (consisting of three judges), with the exception of the investigating court, which hears cases alone. According to the content, the consideration of the case by the said court chamber is a court of first instance. The parties have the right to appeal the decisions of the WACS Judicial Chamber to the WACS Appeals Chamber. The Appeals Chamber is also an independent body of 11 judges. The trial takes place collectively, consisting of three judges. Headed by WACS Chairman of WACS. Appeals against the decisions of the WACS Appeals Chamber are made to the panel of the Criminal Court of Cassation of the Supreme Court, which specializes exclusively in corruption cases.

Courts of general jurisdiction consider criminal proceedings on corruption criminal offenses under investigation by NPU, SBI, SSU; cases under administrative protocols drawn up by NACP and NPU; cases of bringing to civil responsibility for corruption offenses.

Security Service of Ukraine (SSU). The SSU is a special-purpose body endowed with law enforcement functions. The SBU is responsible for conducting operational and investigative activities, including corruption offenses.

Asset Recovery and Management Agency (ARMA) is an executive body responsible for identifying and tracing assets derived from corruption offenses and managing such assets (as long as they are under arrest).

Based on the above, it can be concluded that in Ukraine there are 4 institutions with anti-corruption powers, in particular, responsible for the formation of anti-corruption policy and prevention of corruption (The National Agency on Corruption Prevention, Verkhovna Rada of Ukraine, Cabinet of Ministers of Ukraine, Ministry of Justice of Ukraine, National Anticorruption Policy Council); 7 institutions investigating corruption and corruption-related offenses (The National Agency on Corruption Prevention, State Bureau of Investigations, Prosecutor's Office of Ukraine, Specialized AntiCorruption Prosecutor's Office, National Police of Ukraine, Security Service of Ukraine, National Asset Recovery and Management Agency); 2 institutions responsible for the administration of justice (High Anti-Corruption Court and courts of general jurisdiction).

Financing. According to the State Treasury Service and other available sources, as of April 30, 2020, state funding for the maintenance of anti-corruption bodies in Ukraine has been allocated to ARMA - UAH 30.7 million, HAC - UAH 60.3 million, SBI - UAH 174.1 million, NABU UAH 238.9 million, NACP - UAH 116 million, SAP - UAH 18.4 million, SSU - UAH 2 billion 625.9 million.

In total, UAH 3 billion 264.3 million is allocated to combat corruption. (more than 115 million US dollars).

\section{International experience}

The creation of a body of the judiciary, whose activities are aimed at combating corruption in Ukraine is borrowed from world experience. The first anti-corruption court was established in the Philippines (1979). An anti-corruption court was established in Nepal in 1999, and in Indonesia and Pakistan in 2002. In Europe, anti-corruption courts are in place in Croatia (2008), Slovakia (since 2005) and Bulgaria (since 2017). Today, anticorruption courts operate in only 20 countries, including Afghanistan, Bangladesh, Botswana, Burundi, Cameroon, Indonesia, Kenya, Nepal, Pakistan, Palestine, the Philippines, Senegal, and Uganda (the so-called "third world" countries). 
The Republic of Croatia. In Croatia, the anti-corruption system is based on the Office for Combating Corruption and Organized Crime (USKOK). In 2009, Judicial Divisions were established for criminal proceedings within the competence of USCOC. The specialized anti-corruption court has primary jurisdiction over corruption cases, and appeals are heard in the Supreme Court. Anti-corruption courts hear cases of high-level corruption and organized crime. Pursuant to Article 32 of the Law on the Office for the Suppression of Corruption and Organized Crime, the Judicial Departments for Criminal Proceedings under the Jurisdiction of the USCOC have been established in the District and Municipal Courts of Osijek, Rijeka, Split and Zagreb. Judges of the divisions are appointed by the chairman of the court on an annual basis after the relevant decision of the court council (Law on the Office for the Suppression of Corruption and Organized Crime, 2001).

The Republic of Bulgaria. In Bulgaria, the anti-corruption court is a universal parallel court, as the system of anticorruption courts includes both the court of first instance - the Specialized Criminal Court and the Court of Appeal - the Specialized Criminal Court of Appeal. The Supreme Court of Cassation acts as a cassation instance (Stvorennya ta diyal'nist' antykoruptsiynykh sudiv $u$ Bolhariyi, Slovachchyni ta Khorvatiyi Informatsiyna dovidka, pidhotovlena Yevropeys'kym informatsiynodoslidnyts'kym tsentrom na zapyt narodnoho deputata Ukrayiny)

The Special Criminal Court of Bulgaria hears cases of organized crime along with corruption. The Special Criminal Court of Slovakia hears, in addition to corruption and money laundering cases, cases of organized crime and premeditated murder.

The creation of an anti-corruption court was immediately criticized by judges and NGOs. Given that Bulgaria is one of the most corrupt countries in Europe and, accordingly, the high level of corruption in this country today, it is obvious that the anti-corruption court

It should be noted that the AntiCorruption Court of Bulgaria did not justify the purpose of its creation and did not become a catalyst for overcoming corruption in the country.

The Slovak Republic. The specialized anti-corruption court has primary jurisdiction over corruption cases, and appeals are heard in the Supreme Court. The anti-corruption court was formed of new judges. The legislator enshrined a number of guarantees and rights, such as: high judicial remuneration, personal protection, protection of judges. In Slovakia, there has been a problem with the severance of local ties between judges, lawyers, prosecutors and organized crime. During the first years of the anti-corruption court, certain results were achieved: special knowledge was accumulated, some local criminal ties were severed, and several cases were successfully completed.

There was opposition from politicians and judges of general courts, in connection with which the law on specialized anticorruption court was repealed in 2009 due to a constitutional appeal. However, due to public demands, the court resumed work the same year.

The grounds for the constitutional submission were: high salaries of judges of a specialized court, which was discrimination against other judges; security screening for judges, the requirements of which did not comply with the principle of independence of the judiciary; personal jurisdiction of the court over high-ranking officials.

Today, the specialized court of Slovakia consists of 14 judges, and the specialized prosecutor's office consists of 19 prosecutors. This court hears the most socially dangerous categories of cases: premeditated murders, economic offenses involving more than 6.6 million euros, serious crimes committed by criminal, terrorist groups and extremist crimes. 
Thus, each legal system has its own specifics. In one case, anti-corruption courts are courts of first instance, whose appeals against decisions go immediately to the country's Supreme Court (Croatia and Slovakia). Bulgaria has a parallel system of anti-corruption courts (court of first instance and appellate court). Most anti-corruption courts deal with a wide range of corruption and corruption-related offenses. In addition, some of the specialized courts classified as anticorruption courts actually have broader jurisdiction, covering not only corruption and corruption-related economic crimes, but also other serious crimes. For example, in Croatia, courts have jurisdiction not only over high-level corruption offenses, but also over organized crime. The jurisdiction of the Specialized Criminal Court of Bulgaria (and the relevant Court of Appeal, the Specialized Criminal Court of Appeal) similarly covers organized crime and corruption. Jurisdiction 7 of the Specialized Criminal Court in Slovakia extends to organized crime and premeditated murder, as well as corruption and money laundering.

Denmark is one of the leading countries in the world as the least corrupt country. It is in Denmark that the implementation of anti-corruption laws at the state level and the high legal awareness of citizens are most effective.

The most effective measure to prevent corruption in Denmark is the Danish Law on Corruption, adopted in 2002. According to the law, the Danish government is obliged to publish information on its property and personal income every year. To prevent officials from using their official position for personal purposes, they are obliged to sell their shares in foreign companies.

Paragraph 20 of the Rules of Procedure of the Danish Parliament states that any Member has the right to receive information on the position of any Minister on a matter within his / her competence. In this regard, the parliament holds regular meetings at which ministers respond to inquiries from their colleagues about suspicions of bribery or lobbying the interests of any company.

DANIDA, an international development agency, has extensive experience in combating corruption in Denmark. Agreements concluded by this agency must be accompanied by the signing of a declaration of non-use of bribes. Failure to comply with the provisions on bribery leads to the termination of the contract and the agency's refusal to cooperate with the violator in the future. Besides to the standard anti-corruption regulations, the company has also launched a hotline that allows people to notify the company's management of the illegal use of finances (Anti-corruption bodies of European countries: key preventive mechanisms Enhanced Public Sector Transparency and Integrity Project, 2016).

Significant anti-corruption in Denmark is provided by the Danish Export Credit Agency. Applicants to the agency are required to sign a declaration of nonbribery, which implies a refusal to participate in corrupt practices. In case of breach of the signed agreements, which resulted in financial losses, the applicants are obliged to pay compensation to the agency. In addition, the applicant loses the right to cover losses under the guarantee issued by the agency earlier.

The main task of the Trade Council is to fight corruption in Denmark in foreign markets. The organization helps to conclude deals in international markets while maintaining the good reputation of Danish companies. The Council assists in resolving both ordinary business issues that require consultation and complex issues that cannot be resolved without the assistance of the local government. The Council pursues a policy of "absolute intolerance", which is a good example of non-acceptance of corruption for employees of the organization. 
Industrialization Fund for Developing Countries (IFU). The purpose of the fund is to help expand business abroad by investing in international companies in developing countries with the support of Denmark. The fund provides advisory services, participation in the authorized capital, loans, and guarantees on commercial terms for investments in the service sector. Speaking about how the staff of this organization fights corruption in Denmark, it should be noted that when signing loan and equity participation agreements, the fund actively uses typical anti-corruption provisions.

Slovenia. The system of anti-corruption bodies in Slovenia consists of the following:

- Commission for the Prevention of Corruption (CPC).

- Secretariat (legal, financial, and personnel functions; international cooperation and PR; analysis, investigation, and information security department).

- Bureau of Investigation and Supervision (investigation of corruption, conflict of interest, lobbying, other administrative investigations, collection and monitoring of property declarations, application of rules on conflict of interest, protection of informants, cooperation with law enforcement agencies and the prosecutor's office).

- Center for Prevention of Corruption and Integrity of the Civil Service (coordination of the National Action Plan to Combat Corruption; development of integrity plans (for institutions); development and implementation of anticorruption measures; examination of legislation, cooperation with CSOs, universities, research institutions).

- The Commission for the Prevention of Corruption of Slovenia enjoys the high trust and significant authority in society, according to a report by the National Agency for the Prevention of Corruption. This is one of the first institutions to start working with illegal lobbying of interests through a special database (Anti- corruption bodies of European countries: key preventive mechanisms - Enhanced Public Sector Transparency and Integrity Project, 2016).

Macedonia. The State Commission for the Prevention of Corruption is the main anti-corruption institution in Macedonia. It reviews all reports of suspected corruption: both those it has investigated on its own and media reports, complaints, and informants.

The Commission includes a Secretariat, which can be divided into the Human Resources and Internal Audit Sectors. The Human Resources Sector includes the Sector for the Prevention of Corruption and Conflicts of Interest, which includes: the Department for the Prevention of Corruption (in politics, public administration, public interest, economic sphere), the Department for Maintenance of Registers and Monitoring of Property (monitoring of the property, maintenance of registers, etc.), Department of Conflict of Interest Prevention (monitoring of the state conflict of the interest prevention program and collection of information on conflicts of interest). The internal Audit Sector includes the Sector of Program, Analytical Work, Financial and Administrative Issues, which includes the Department of International Programs and Analytics (programs, analytics, monitoring of the State Program for Prevention and Overcoming Corruption), the Department of Public Relations (Public Relations), Department of Financial, Administrative and Personnel issues (financial issues and budget preparation, IT, archiving) (Anticorruption bodies of European countries: key preventive mechanisms - Enhanced Public Sector Transparency and Integrity Project, 2016).

At the beginning of its establishment, the SCPC received public support, which provided an opportunity to legitimize its activities. However, political influence over the Commission has increased since 2007. As a result, this led to the loss of a clear position and influence of the SCPC. The 
SCPC's mandate covers exclusively the implementation and monitoring of the anticorruption strategy, monitoring of changes in property status, special training for civil servants, cooperation with public authorities and international institutions. Imperfect legislation, which is manifested in the absence of proportional punishment for the act, lack of deadline for filing an annual property declaration, lack of a clear list of civil servants, lack of a comprehensive online filing system and full automatic integration with other state registers to verify declarations.

Serbia. The Anti-Corruption Agency includes the following divisions: Civil Servants' Property and Revenue Department (Registers and Supervision Department), Complaints Department (Registration and Initiation Group, Complaints Department, Informant Protection Group), International Cooperation Department (Group EU Integration, International Projects Group), Political Finance Supervision Department (Financial Reporting Supervision Department, Legal Department), Prevention Department (Education, Civil Society and Analysis Department, Strategies Implementation Supervision Department, Plan Action and Legislation, Integrity Plans Division), General Affairs Division, Conflict of Interest Office (Conflict of Interest Division, Management Transfer Supervision Division), IT Group.

A positive aspect of this structure is the high awareness of the public about the mechanisms of prevention and supervision of the Anti-Corruption Agency through PR campaigns. At the same time, the high authority of the Anti-Corruption Agency does not fully meet the expectations of citizens due to limited powers. An imperfect regulatory framework creates shortcomings in the process of cooperation with other government agencies. Also, gaps in the legislation lead to a decrease in the effectiveness of the Anti-Corruption Agency in conducting inspections for signs of corruption offenses in the actions of certain persons. The Anti-Corruption Agency does not have the right to initiate proceedings on anonymous complaints, which also reduces the efficiency of the AntiCorruption Agency. The powers of the agency, in this case, are limited solely to the possibility of transmitting information on anonymous complaints to other government agencies (Anti-corruption bodies of European countries: key preventive mechanisms - Enhanced Public Sector Transparency and Integrity Project, 2016).

Latvia. Corruption Prevention and Combating Bureau of Latvia includes the following divisions: Civil Servants Control Division, Political Party Finance Control Division, Policy Planning Division, Office, Legal Division, Finance Division, Administrative Division, Internal Security Division, Criminal Intelligence Division, Investigation Division, intelligence support department.

A feature of the Corruption Prevention and Combating Bureau of Latvia is that. That they conduct dozens of training events (training) a year. Most of these activities are aimed at raising awareness of anti-corruption legislation, professional ethics rules, and internal institutional compliance mechanisms for civil servants. In addition to these measures, measures are also taken to raise public awareness of anti-corruption legislation: compliance and implementation of the law (Anti-corruption bodies of European countries: key preventive mechanisms - Enhanced Public Sector Transparency and Integrity Project, 2016).

The positive aspects of Latvia's experience with the institutional structure of the Corruption Prevention and Combating Bureau of Latvia include the preparation and implementation of an anticorruption strategy, conflict of interest management and training.

Romania. National Integrity Agency (NAD), which includes the Main Registration Service, the Personnel Service, 
the Economic Directorate, the five Integrity Verification Services, the General Directorate for Legal Affairs, Public Relations and Communications (Legislation Department, Judicial Service, communications, public relations and strategy, IT service, IT infrastructure management, service information management).

A positive aspect of the NAD's activity is that information from the media, responsible officials from government agencies can be a sufficient basis for initiating an investigation.

The effectiveness of this institution is confirmed by a significant number of winning lawsuits in favor of the NAD, initiating the process of returning assets to the state budget. However, it should be noted that there are legal conflicts that hinder the activities of the NAD (Anticorruption bodies of European countries: key preventive mechanisms - Enhanced Public Sector Transparency and Integrity Project, 2016).

\section{Activity of the High Anti-} Corruption Court and Other AntiCorruption Bodies of Ukraine

O. Prokhorenko emphasizes that the typical shortcomings of anti-corruption legislation are the lack of system and coherence of norms that could be the basis for the application of measures to combat corruption. In addition, the unstable political situation has a significant impact, which leads to staff turnover in the field of public administration (Prokhorenko, 2005).

We agree with this thesis of the scientist. Also, given the above, it should be noted that in addition to the lack of systemic and consistent norms, there is no effective system of anti-corruption bodies. The accumulation of bodies of different legal status, as practice shows, does not help to improve the situation in the country on the way to overcoming corruption. This fact necessitates taking into account the experience of countries with relatively low levels of corruption, countries that are rapidly improving indicators to combat corruption in order to Europeanize not only the current legislation of Ukraine, but also Europeanization of the mentality of the Ukrainian people to combat this phenomenon.

The UN and Council of Europe Conventions against Corruption define such criteria for the effectiveness of specialized anti-corruption bodies as independence, specialization, proper training and adequate resources.

Our most effective system of anticorruption institutions could be a system consisting of the following bodies:

Group I includes bodies endowed with anti-corruption powers, in particular responsible for the formation of anticorruption policy and prevention of corruption (with the absorption of the powers of the NAPC in terms of anticorruption strategy):

- Verkhovna Rada of Ukraine,

- Cabinet of Ministers of Ukraine,

- Ministry of Justice of Ukraine,

- National Anticorruption Policy Council.

Group II includes bodies investigating corruption and corruption-related offenses:

- NABU (taking into account the anti-corruption powers of the SBI and NACP).

- Prosecutor's Office (with the preservation of an independent unit of the Office of the Prosecutor General of the SAP)

- National Police of Ukraine.

Group III includes the bodies responsible for the administration of justice:

- Court (courts of general jurisdiction).

The feasibility of this system is as follows:

ARMA. It is stated that ARMA was established by analogy with asset recovery and management institutions that operate 
successfully in the EU Member States in accordance with the decision of the Council of the European Union № 2007/845 / JHA of 06 December 2007 and other acts of EU law. However, the legislator introduced the provision on ARMA without harmonizing the current system of anti-corruption institutions. The main powers of ARMA are to identify and search for assets that have been illegally removed from Ukraine as a result of corruption and other criminal offenses, as well as the need to introduce transparent and effective mechanisms for managing seized assets, as well as the formation and maintenance of the Unified State Register of Assets. arrested in criminal proceedings. It seems doubtful that with the large number of anticorruption institutions in Ukraine there was a real need to create ARMA, as the authority to identify and search assets by content can be attributed to operational and investigative activities, which in turn corresponds to the legal status of NABU or SBI. carries out operative-search measures. Regarding the maintenance and formation of the Unified Register of Assets, it should be noted that the NACP could perform these powers as of today, as the latter is responsible for the administration of the Unified State Register of declarations of persons authorized to perform state or local government functions; Unified State Register of Persons Who Have Committed Corrupt or Corruption-Related Offenses; Unified State Register of Financial Statements of Political Parties.

NACP. As practice and public opinion show, the NACP absolutely does not justify its obligations. The powers of the NACP are abstract, which in turn creates competition with the powers of the NABU and the SBI in terms of operational and investigative activities in relation to corruption offenses, for the commission of which a person is brought to administrative responsibility. The division of powers according to the degree of public danger is in itself nonsense, because when conducting an investigation, persons working in these bodies cannot knowingly find out all the circumstances that have legal significance.

NABU became the first anti-corruption body to have a significant range of powers. In our opinion, in order to comply with the anti-corruption strategy, it is advisable to expand the powers of NABU.

SBI is legally close to NABU. The difference is in the subjective composition of the persons in respect of whom these bodies are authorized to carry out intelligence activities. It seems questionable to create two bodies of similar legal nature, instead of expanding the NABU staff and expanding the powers, which would lead to the absence of problems with the distribution of jurisdiction and competence and reduce public funding.

HAC. The fact of the creation of HAC provoked a mixed reaction from society. The positive features of the newly established institution were to be independence, impartiality, high professionalism of the judiciary, the implementation of the principle of inevitability of punishment, and as a consequence, a significant reduction in corruption.

The main arguments for the inexpediency of the creation and inefficiency of HAC can be considered the following:

- Long-term consideration of cases that end with the appointment of a fairly lenient punishment or closure of cases due to the omission of time limits for prosecution;

- No need to create a specialized body of the judiciary for a specific category of cases;

- A small number of cases considered by HAC;

- Artificial creation of an additional vertical of courts.

The experience of Ukraine and foreign countries, which have established anticorruption courts, indicates that the expectations regarding the effectiveness of 
this anti-corruption body have not yet materialized. During the year of activity in the court proceedings there were almost 300 cases, in 16 of which he has already announced verdicts. However, there are no convictions for corruption at the highest level yet.

In early 2019, Transparency International Ukraine provided 12 recommendations that could improve Ukraine's performance in CPI. As of the end of the year, only 6 of them were implemented or partially implemented, and those in the last quarter of 2019.

Among them were the abolition of the SSU monopoly on wiretapping (removal of information from transport telecommunications networks) and the abolition of the state monopoly on examinations, which will avoid artificially delaying the investigation.

The Verkhovna Rada also regulated the procedure for handing over suspicion to special entities, as there were frequent cases of abuse by the defense. At the same time, the criminal procedure code still has provisions that negatively affect the quality and effectiveness of pre-trial investigations. In particular, detectives are still limited in their activities during the investigation, which is likely to adversely affect its completeness.

On June 6, 2019, the Constitutional Court of Ukraine declared unconstitutional the provisions of paragraph 5 of part one of Article 3, paragraph three of part three of Article 45 of the Law of Ukraine "On Prevention of Corruption" of October 14, 2014 № 1700 - VII as amended (hereinafter - Law № 1700), paragraph 2 of Section II "Final Provisions" of the Law of Ukraine "On Amendments to Certain Laws of Ukraine on Peculiarities of Financial Control of Certain Categories of Officials" of March 23, 2017 № 1975 - VIII (hereinafter - Law № 1975) on Electronic Declaration of Anti-Corruption Public Activists. The Court concluded that these provisions violated the constitutionally guaranteed freedom of political and public activity and could be used for persecution.

Four recommendations were partially implemented in Ukraine. On October 18, the law came into force, which began to reset the NACP. The agency lost its collegiality, and the head was elected with the participation of international experts. At the end of the year, the NACP received automated access to verify e-declarations of the 3 required registers that remained unconnected.

After the early parliamentary elections, on September 19, 2019, a bill in the field of public procurement was adopted. The new law came into force on April 19, 2020 and is harmonized with EU standards. At the same time, the issue of effective monitoring of procurement by the State Audit Office remains relevant.

The Verkhovna Rada provided for the possibility of privatizing 500 state-owned enterprises through the ProZorro.Sale electronic auction system. In October 2019, the Verkhovna Rada lifted the ban on the privatization of a number of state-owned enterprises.

In October 2019, the Bankruptcy Code came into force and the Cabinet of Ministers adopted a resolution on conducting electronic auctions for the sale of property of insolvent enterprises through the ProZorro.Sales system.

The practice of using open budgets is growing moderately. In particular, Ukraine has a state budget web portal for citizens. The government has agreed on the composition of supervisory boards in a number of state-owned enterprises, including the Ukrainian Seaports Administration, Boryspil International Airport, Ukrzaliznytsia, and Ukrhydroenergo. However, in the previous year, the process of establishing supervisory boards in local communities at utilities did not accelerate significantly (Transparency International Ukraine, 2019). 
The following recommendations were not implemented:

- Ensuring the effective operation of the register of beneficiaries;

- Strengthening control over the financing of political parties;

- Changing the method of forming judicial self-government bodies;

- Restoration of trust in the Specialized Anti-Corruption Prosecutor's Office.

Deprivation of the SSU and the National Police of powers in the fight against economic crime "Punish those responsible for organizing attacks on anticorruption activists".

Given the above, in our opinion, it would be appropriate to introduce the following system of anti-corruption bodies (Transparency International Ukraine, 2019).

Among the countries where bodies similar to the powers of the SSU are deprived of investigative functions are: Lithuania, Slovenia, Slovakia, Croatia, Montenegro. Cases where countries provide state security services to investigators are rare and the effectiveness of those powers has not been proven. I think we should start talking about the expediency of depriving the SSU of investigative functions, as evidenced by the experience of European countries.

We believe that the key point in the process of improving the effectiveness of the fight against corruption in Ukraine is the need to implement the experience of European countries in terms of informing and training civil servants in professional ethics, raising awareness and legal culture of citizens. In particular, Romania's experience in the adequacy of media information to verify the accuracy of information and conduct investigative actions can be considered useful. The high authority of anti-corruption bodies, as evidenced by the analyzed practice of the EU, determines the effectiveness of the fight against corruption.
On most information sites of anticorruption bodies, citizens ask questions about the legal nature and questions related to the procedure for appealing in case of corruption offenses. For example NABU. As a general rule, these authorities recommend that you first check whether the information is relevant to NABU detectives, after which the person should make sure that the information relates to NABU detainees, and only then call the hotline. It seems logical that not all citizens can properly qualify the act they have witnessed. The legislator was guided by the logic of creating such a complex system of anti-corruption bodies in order to avoid information leakage, impartiality of officials. However, the logical question is to protect the whistleblower and to preserve the confidentiality of the information communicated by the person to all bodies known to him due to low legal awareness.

Such a system of anti-corruption institutions will help to clearly establish powers, avoid conflicts of interest and bureaucratic schemes, increase the targeted use of budget funds, facilitate citizens' access to relevant bodies with complaints about corruption offenses, and eliminate the privileged status of corrupt officials in the administration of justice.

\section{CONCLUSIONS}

Therefore, based on the above, we can draw the following conclusions. Today, the activities of the Supreme Anti-Corruption Court and anti-corruption bodies of Ukraine in the context of Europeanization are aimed at overcoming corruption. The term "corruption" should be understood as a complex negative social phenomenon, which is due to historical and political processes in the state and psychological features of human thinking, which manifests itself in improper performance or non-performance by public administration officials to satisfy personal interests. The main task of the government, in our opinion, is not to overcome, but to minimize corruption. One of the key 
elements in the fight against corruption is the creation of an effective system of anticorruption bodies and a regulatory framework for their proper interaction. Based on the above, it can be concluded that in Ukraine there are 4 institutions with anti-corruption powers, in particular responsible for the formation of anticorruption policy and prevention of corruption (The National Agency on Corruption Prevention, (Verkhovna Rada of Ukraine, Cabinet of Ministers of Ukraine, Ministry of Justice of Ukraine, National Anticorruption Policy Council); 7 institutions investigating corruption and corruption-related offenses (National AntiCorruption Bureau of Ukraine, prosecutor's offices, Specialized Anti-Corruption Prosecutor's Office, National Police, State Bureau of Investigation, Security Service of Ukraine, Asset Recovery and Management Agency); 2 institutions responsible for the administration of justice and prosecution of persons for corruption (High AntiCorruption Court of Ukraine and courts of general jurisdiction).

Today, there are 20 countries in the world where anti-corruption courts have been established. Each legal system has its own specifics. In one case, anti-corruption courts are courts of first instance, whose appeals against decisions go immediately to the country's Supreme Court (the Republic of Croatia and the Slovak Republic). The Republic of Bulgaria has a parallel system of anti-corruption courts (court of first instance and appellate court). On the example of the analysis of the experience of European countries, the effectiveness of the creation of such a body remains questionable. The Supreme AntiCorruption Court in Ukraine has become a revolutionary step for Ukraine. The positive features of the newly established institution were to be independence, impartiality, high professionalism of the judiciary, the implementation of the principle of inevitability of punishment, and as a consequence, a significant reduction in corruption. However, as practice has shown, the main arguments for the inexpediency of the establishment and inefficiency of the HAC can be considered the following: no need to create a specialized body of the judiciary for a specific category of cases, a small number of cases considered by the HAC, the artificial creation of an additional vertical of courts.

The accumulation of bodies of different legal status, as shown by European and domestic practice, does not help to improve the situation in the country on the way to minimizing corruption. This fact necessitates taking into account the experience of countries with relatively low levels of corruption; countries that are rapidly improving indicators to minimize corruption in order to Europeanize not only the norms of current legislation of Ukraine, but also the Europeanization of the mentality of the Ukrainian people on the way to combat this phenomenon.

It was emphasized that the most effective system of anti-corruption institutions could be a system consisting of the following bodies: I group of bodies endowed with anti-corruption powers, in particular responsible for anti-corruption policy and corruption prevention (with absorption of NACP powers in terms of Anti-Corruption Strategy): The Verkhovna Rada of Ukraine, Cabinet of Ministers of Ukraine, Ministry of Justice of Ukraine, National Anticorruption Policy Council. Group II of bodies investigating corruption offenses and corruption-related offenses. NABU (taking into account the anticorruption powers of the SBI and NACP). Prosecutor's Office (with the preservation of an independent unit of the Office of the Prosecutor General of the SAP) National Police. III group of bodies responsible for the administration of justice. Court (courts of general jurisdiction).

With regard to ARMA, it should be noted that it is doubtful that with the large number of anti-corruption institutions in Ukraine there was a real need to create ARMA, as the authority to identify and 
search assets by content can be attributed to operational and investigative activities, which in turn the legal status of NABU or SBI, which directly carries out operational and investigative measures.

As for the SSU, it was found that among the countries where bodies similar to the powers of the SSU are deprived of investigative functions are: Lithuania, Slovenia, Slovakia, Croatia, Montenegro. Cases where countries provide state security services to investigators are rare and the effectiveness of those powers has not been proven. I think we should start talking about the expediency of depriving the SSU of investigative functions, as evidenced by the experience of European countries.

Given the above, we believe that a key point in the process of improving the effectiveness of the fight against corruption in Ukraine is the need to implement the experience of European countries also in terms of informing and training civil servants professional ethics, awareness and legal culture. In particular, Romania's experience in the adequacy of media information to verify the accuracy of information and conduct investigative actions can be considered useful. The high authority of anti-corruption bodies, as evidenced by the analyzed practice of EU countries (including Denmark), determines the effectiveness of the fight against corruption. Such a system of anticorruption institutions will help to clearly establish powers, avoid conflicts of interest and bureaucratic schemes, increase the targeted use of budget funds, facilitate citizens' access to relevant bodies with complaints about corruption offenses, and eliminate the privileged status of corrupt officials in the administration of justice.

\section{References}

Akimov, O. O. (2014). Psykholohichni aspekty proiaviv koruptsii $\mathrm{v}$ derzhavnomu upravlinni [Psychological aspects of corruption in government]. Derzhavne upravlinnia: teoriia ta praktyka, 1, 181-
188. Retrieved August 1, 2020, from: http://nbuv.gov.ua/UJRN/Dutp 201 4123 (in Ukrainian)

Antykoruptsiini orhany krain Yevropy: kliuchovi preventyvni mekhanizmy [Anticorruption bodies of European countries: key preventive mechanisms]: Zbirka-zvit krashchykh praktyk dlia Natsionalnoho ahentstva z pytan zapobihannia koruptsii. Proekt "Prozorist i dobrochesnist publichnoho sektoru" [Enhanced Public Sector Transparency and Integrity Project]. 2016. Retrieved August 1, 2020, from: http://www.dhrp.org.ua/images/ne wsarticles/20160219/Commission ua sma ll.pdf (in Ukrainian)

Betsa, I., \& Sheremetieva L. (2009). Osnovy poniattia "ievropeizatsiia" ta yoho sens u suchasnomu suspilstvi [Fundamentals of the concept of "Europeanization" and its meaning in modern society]. Yevropeizatsiia publichnoho administruvannia $\mathrm{v}$ Ukraini $\mathrm{v}$ konteksti yevropeiskoi intehratsii: Materialy naukovo-praktychnoi konferentsii (m. Dnipropetrovsk, 17 hrudnia 2009 r.). Dnipropetrovsk: DRIDU NADU (p. 36-39). Retrieved August 1, 2020,

from: http://www.dridu.dp.ua/konf/konf dridu/2009 12 17\%20konf.pdf $\quad$ (in Ukrainian)

Bryce, J. (1921). Modern Democracies. New York: Macmillan. 2 vols. Vol. 2. (pp. 149-150). Retrieved August 1, 2020, from: https://oll.libertyfund.org/titles/209 $\underline{0}$

Corruption Perceptions Index, CPI (2019). Transparency International Ukraine. Retrieved August 1, 2020, from: $\quad$ https://tiukraine.org/research/indeks-spryjnyattyakoruptsiyi-2019/(in Ukrainian)

Dimant, E., \& Schulte, T. (2016). The Nature of Corruption: An Interdisciplinary Perspective. German Law Journal, 17(1), 53-72.

doi: https://doi.org/10.1017/s207183220 $\underline{0019684}$ 
Dreher, A., Kotsogiannis, C., \& McCorriston, S. (2004). Corruption Around the World: Evidence from a Structural Model. SSRN Electronic Journal. doi: http://dx.doi.org/10.2139/ssrn.55594 $\underline{6}$

Friedrich, Carl J. (2017). Corruption Concepts in Historical Perspective / Edited by A. J. Heidenheimer, M. Johnston. Political Corruption: Concepts and Contexts. Third Edition. New York: Routledge, 15-24 (850 p).

Gasparov, M. L. (ed.) (1991). Antichnaya poetika. Ritoricheskaya teoriya i literaturnaya praktika [Antique poetics. Rhetorical theory and literary practice]: sbornik. Moskva: Nauka, 1991. (254 p) (in Russian)

Heidenheimer, A. I., \& lohnston, M. (2017). Political Corruption: Concepts and Contexts. 3rd Edition. New York: Routledge (850

p.). doi: https://doi.org/10.4324/9781315126 $\underline{647}$

Law on the Office for the Suppression of Corruption and Organized Crime (Law of Croatia), № 1497, NN 88/2001, from:https://www.zakon.hr/z/166/Zakon -o-Uredu-za-suzbijanje-korupcije-i-

organiziranog-kriminaliteta

Mikhel, D. O. (2011). Vyznachennia poniattia protsesu "ievropeizatsiia" ta yoho vplyv na suchasne suspilstvo [Definition of the concept of the process of "europeanization" and its impact on modern society]. Naukovi pratsi [Chornomorskoho derzhavnoho universytetu imeni Petra Mohyly]. Ser.: Politolohiia, 162(150), 22-25. Retrieved August 1, 2020, from: http://nbuv.gov.ua/U/RN/Npchdupo $\underline{120111621507}$

Nevmerzhytskyi, Ye. V. (2008). Koruptsiia v Ukraini: prychyny, naslidky, mekhanizmy protydii [Corruption in Ukraine: causes, consequences, countermeasures]. Kyiv: KNT (363 p.). Retrieved August 1, 2020, from:
nbuv.gov.ua/ulib/item/UKR0002185 (in Ukrainian)

Nye, J. S. (1967). Corruption and Political Development: A Cost-Benefit Analysis. American Political Science Review, 61(2), 417-427. doi: https://doi.org/10.2307/1953254

On the High Anti-Corruption Court (Law of Ukraine). № 2447-VIII 07.06.2018. Retrieved August 1, 2020, from: https://zakon.rada.gov.ua/laws/sho w/2447-19\#Text (in Ukrainian)

On the National Anti-Corruption Bureau of Ukraine (Law of Ukraine). 14.10.2014, № 1698-VII. Retrieved August 1 , 2020,

from: https://zakon.rada.gov.ua/laws/sho w/1698-18\#Text (in Ukrainian)

On the National Council for AntiCorruption Policy (Decree of the President of Ukraine). 14.10.2014, № 808/2014. Retrieved August 1, 2020, from: https://zakon.rada.gov.ua/laws/sho w/808/2014\#Text (in Ukrainian)

Prokhorenko, O. Ya. (2005). Koruptsiia po-ukrainsky (sutnist, stan, problemy) [Corruption in Ukrainian (essence, state, problems)]. Kyiv: Vydavnytstvo NADU (166 p.) (in Ukrainian)

Soloviov, V. (2011). Istorychna geneza koruptsii [Historical genesis of corruption]. Naukovi zapysky Instytutu zakonodavstva Verkhovnoi Rady Ukrainy, 5(8), 22-26 (in Ukrainian)

Stvorennya ta diyal'nist' antykoruptsiynykh sudiv u Bolhariyi, Slovachchyni ta Khorvatiyi Informatsiyna dovidka, pidhotovlena Yevropeys'kym informatsiyno-doslidnyts'kym tsentrom na zapyt narodnoho deputata Ukrayiny [Creation and activities of anti-corruption courts in Bulgaria, Slovakia and Croatia. Information note prepared by the European Information Center on request of the people's deputy of Ukraine], from: http://euinfocenter.rada.gov.ua/uplo ads/documents/29287.pdf (in Ukrainian)

The Oxford English Dictionary. Oxford Dictionaries. Retrieved August 1, 2020, 
from: https://languages.oup.com/research Loxford-english-dictionary/

Wilkinson, T., \& Loiko, S. L. (2019). Here is what Joe Biden actually did in Ukraine. Los Angeles Times (oct. 5, 2019). Retrieved August 1, 2020, from: https://www.latimes.com/politics/st ory/2019-10-05/bidens-visits-to-ukraineunder-scrutiny
Yurinets, Y. (2015). Yevropeizatsiia administratyvnoho prava Ukrainy: teoretyko-metodolohichni zasady [Europeanization of administrative law in Ukraine: theoretical and methodological foundations]. Yurydychnyi visnyk. Povitriane i kosmichne pravo, 4, 80-87. Retrieved August 1, 2020, from: http://nbuv.gov.ua/UJRN/Npnau 20 $\underline{15417}$ (in Ukrainian) 


\title{
Theory of judicial security
}

\author{
Olesia Bordun ${ }^{1}$
}

Received: 2021-02-26

Accepted: 2021-04-02

DOI: http://doi.org/10.46489/gpj.2021-1-1-2

Abstract. In this article, we have attempted to generalise the current theory of judicial security. We emphasised that traditionally the judicial security theory includes a set of scientific views on the security of the court, judge, justice system and participants in the trial, and the status of the Judicial Protection Service. We briefly described the history of judicial security and drew attention to the reforms of recent years. An analysis of international judicial standards has shown that the security of the judiciary correlates to its independence. We proposed an interdisciplinary adaptation of the judicial security methodology, considering the limitations of specialised research on the subject. As a result, we concluded that the lack of a sole methodological guideline produces uncorrelated changes in the judicial security system elements. To systematise the theory of security of the judiciary, we propose to consider the methodological basis of international standards of justice.

Keywords: judicial power, judicial security, international standards of judiciary, judicial reform.

1 Olesia Bordun, lecturer, Department of judiciary, prosecution and advocacy, Lviv university of business and law, Kulparkivska, 99, 79021 Lviv, Ukraine, e-mail: olbordun@meta.ua, ORCID: https://orcid.org/0000-00032801-0609 


\section{ВСТУП}

Очевидно, що вирішення глобальних проблем безпеки судової влади на рівні підзаконних актів $\epsilon$ практично неможливим, свідченням чому став, зокрема, перехідний період від ліквідації спецпідрозділу «Грифон» до утворення СCO, на час якого питання безпеки судів регулювалось підзаконними актами та було доволі проблемним. Глобальний погляд на проблематику безпеки судової влади вимагає, з методологічної точки зору, не лише уваги до нормативно-правових основ її організаційного забезпечення, але й встановлення загальних вимог до судоустрійного законодавства, яким визначаються нормативні засади відповідних процесів. У такому ракурсі доходимо висновку про доцільність послідовного аналізу також міжнародних стандартів правосуддя, виконання яких $\epsilon$ умовою втілення євроінтеграційних прагнень України.

Традиційно

розвиток концептуальних засад безпеки судової влади як сукупності наукових поглядів щодо безпеки суду, судді, органів системи правосуддя та учасників судового процесу, а також статусу Служби судової охорони відбувається у методологічних рамках принципу незалежності суду (Council of Judges of Ukraine, 2018).

На жаль, у сучасних наукових працях як українських, так і іноземних авторів не спостерігається комплексного підходу у поглядах на безпеку судової влади. Досліджуючи певні елементи, якто фізичну безпеку суду або ж безпеку судді, науковці часто обмежуються ними, не розглядаючи безпеку судової влади як систему, методологічну парадигму, у рамках якої має відбуватись формування концептуальних і правових засад забезпечення безпеки за кожним 3 напрямків. Отже, для напрацювання методичного підходу, що дозволить обгрунтувати організаційно-правовий механізм забезпечення безпеки судової влади, звернемо увагу на наступне.

Відтак, метою статmі $\epsilon$ узагальнення теорії безпеки судової влади.

\section{РЕЗУЛЬТАТИ}

Досліджуючи питання правоохоронного забезпечення судочинства в Україні, Пчелін В. Б. (2017) звернув увагу на те, що в умовах недостатнього фінансування Служби судової охорони ДСА України завдання із правоохоронного забезпечення судочинства покладаються на органи поліції й Національної гвардії, котрі, у зв'язку 3 недостатнім кадровим потенціалом і неналежним фінансуванням не можуть в ефективній спосіб виконувати таке завдання. Науковець підкреслює, що через відсутність належного правоохоронного забезпечення діяльності органів судової влади, принцип незалежності судді й судової гілки влади загалом зазнає чималих порушень. Аналізуючи ще у 2010 р. перспективи реформування служби судової міліції, Ігонін Р. В. (2010) наголошував, що такий орган має відноситись до системи судоустрою України та бути підпорядкованим i підконтрольним органам суддівського самоврядування. До основних повноважень, якими на думку науковця мав би володіти відповідний орган, слід було б відносити право складати протоколи про адмінпорушення i накладати адмінстягнення за вчинення будь-яких адмінпорушень що посягають на авторитет правосуддя або перешкоджають нормальному функціонуванню суду, зокрема, прояв неповаги до суду, невжиття заходів щодо виконання окремої ухвали суду та ін.

Вже у пореферменний період організаційно-правові проблеми створення та діяльності служби судової охорони в Україні дослідили Зуєва I.I. та 
Приступ B.M. (2019). Науковцями досліджено повноваження ССО, виявлено проблемні питання механізму їх реалізації та законодавчі неузгодження затверджених положень, запропоновано шляхи вирішення проблем. Науковці доходять висновку, що у нормативному плані за результатами проведених реформ «створено потужну і водночас громіздку інституцію зі складним механізмом регулювання, який дублює повноваження працівників Національної поліції, Національної гвардії тощо, проте прямо не передбачає взаємодії між ними, що потребує законодавчого вирішення». Доцільною науковці вважають також реорганізацію Служби судових розпорядників 3 підпорядкуванням її ССО.

Питання державного контролю за діяльністю ССО досліджував Кіпчарський О. М. (2020). У його праці знайшла обгрунтування теза про те, що державний контроль за діяльністю ССО $\epsilon$ системою організаційно-правових форм забезпечення додержання принципу верховенства права, виконання поставлених завдань та реалізації управлінських рішень в діяльності Служби судової охорони, який здійснюється ДСА України та ВРП задля забезпечення безпеки i незалежності суду.

Шпенова П. Ю. (2019), досліджуючи питання організації роботи апарату суду торкається також проблематики організаційно-правових засад діяльності ССО. Звертаючи увагу на особливості статусу працівників ССО, а також те, що пости ССО не віднесено до структурних елементів апарату суду, науковець відзначає. що керівник апарату суду або голова суду не мають повноважень щодо вирішення кадрових, дисциплінарних, організаційних питань, які стосуються особового складу постів, визначення порядку їх роботи тощо, а лише можуть вирішувати питання щодо обладнання об'єктів охорони відповідними інженерно-технічними засобами. На думку Шпенової П. Ю., позбавлення голови суду та керівника апарату суду можливості регулювання діяльності ССО може знизити ефективність вирішення багатьох організаційних та функціональних питань на місцях.

Бачимо, що предметна область організаційно-правових засад утворення та функціонування ССО $\epsilon$ доволі вузькою та не стосується декількох важливих питань, зокрема, захисту судової влади від можливих загроз у найширшому розумінні, а також конкретних гарантій діяльності судді.

3 цього приводу слід погодитись 3 Саленко О. щодо того, що «Інтеграційні процеси, що відбуваються в різних регіонах та на різних континентах між країнами 3 різними правовими традиціями, відрізняються за темпом, способом, формою та змістом. Обов'язковою умовою інтеграційних процесів, що відбуваються у світі, є створення спільного правового простору для регулювання міжнародних відносин через гармонізацію правових приписів національного законодавства із загальновизнаними міжнародними стандартами» (Salenko, 2014, 263).

Досліджуючи міжнародні стандарти ефективності судової системи, Москвич Л. М. (2009) наголошує, що під стандартом слід розуміти певний зразок (еталон, модель), що приймається за вихідний для порівняння 3 ним інших подібних об'єктів чи явищ. Опираючись на результати дослідження Іваночко І. Б. (2015), можемо стверджувати, що міжнародні стандарти правосуддя містяться у таких міжнародних документах, як Європейська хартія про статус суддів, Монреальська універсальна декларація про незалежність правосуддя; Рекомендація CM/REC (2010) 12 КМР€, Висновках КРЕС, a також рекомендаціях Європейської Комісії «За демократію через право». Як підкреслюють Короєд 
C. О. та ін. (2015), ключові міжнародні стандарти дають загальні орієнтири державам у побудові механізмів судочинства та судових систем.

У Основних принципах незалежності судових органів (1985) закріплено, що судові органи вирішують передані їм справи безсторонньо, на основі фактів і відповідно до закону, без будь-яких обмежень, неправомірного впливу, спонуки, тиску, погроз або втручання, прямого чи непрямого, 3 будь-якого боку і з будь-яких би то не було причин. Також наголошується, що не повинно мати місця неправомірне чи несанкціоноване втручання в процес правосуддя, а судові рішення, винесені суддями, не підлягають перегляду. Відповідні положення віднесено до частини, присвяченої гарантіям незалежності судових органів.

Ризики, що можуть виникати у зв'язку з професійною діяльністю судді у контексті розгляду окремих справ, визнаються у міжнародних стандартах як такі, що варті уваги та можуть мати наслідком передачу справи до спеціалізованого суду. Так, у Висновку №8 Консультативної ради європейських суддів до уваги Комітету Міністрів Ради Європи з питання «Роль суддів у захисті верховенства права та прав людини в контексті тероризму» (2006), КРЕС визнає, що «місцеві обставини або потреби, які мають стосунок до безпеки суддів, можуть іноді виправдовувати звернення до спеціалізованих судів, які мають компетенцію щодо справ про тероризм». Також, наприкінці даного висновку, КРЄС підкреслює необхідність забезпечення державою безпеки слідчих, суддів та персоналу судової системи, залучених до вирішення питань, пов'язаних з тероризмом.

У Загальній (Універсальній) хартії судді (1999) спостерігається досить цікавий підхід. Стаття 8 має назву «безпека офісу». Ї̈̈ зміст, однак, вказує на те, що мова йде не про суд, а дійсно про робоче місце судді. Абзац перший цієї статті вказує на те, що суддя не може бути затриманий чи переміщений 3 офісу, за винятком випадків, передбачених законом та тільки на підставі рішення дисциплінарного органу 3 чітким дотриманням процедури. $\mathrm{y}$ абзаці другому вказується на важливість встановлення гарантій забезпечення умов діяльності довічно чи на певний строк, що дозволить «не піддавати небезпеці його незалежність». Останній абзац присвячено гарантії попередження зміни віку виходу судді на пенсію.

Тісний зв'язок безпеки та незалежності судді простежується крізь призму вимог міжнародних стандартів щодо забезпечення фінансової безпеки суддів. Так, у Висновку №11 Консультативної ради європейських суддів до уваги Комітету Міністрів Ради Європи щодо якості судових рішень (2008) наголошується, що якість ухвалення рішень залежить від виділення адекватних людських, фінансових та матеріальних ресурсів кожній судовій системі, а також від забезпечення фінансової безпеки кожного судді у відповідній системі.

у міжнародних стандартах спостерігається достатньо мало конкретних рекомендацій щодо побудови організаційно-правових механізмів забезпечення безпеки судової влади. Чи не єдиним прикладом у цьому контексті є згадка у Висновку №14 Консультативної ради європейських суддів до уваги Комітету Міністрів Ради Європи щодо правосуддя та інформаційних технологій (2011) щодо того, що відео-конференцзв'язок може полегшити проведення судових засідань 3 точки зору покращення безпеки та відібрання свідчень в свідків та експертів.

Як слушно зауважує Корнієвський 0. (2008), суспільна безпека органічно пов'язана 3 особистою безпекою громадян, яка становить комплекс 
суспільних інтересів, спрямованих на захист конституційних прав і свобод людини і громадянина. На думку Тихого В. П. (2016), безпека людини - це об'єктивний стан і суб'єктивне відчуття фізичної, майнової, соціальної (матеріальної), психологічної i моральної захищеності людини, iї прав і свобод. Людина перебуває в безпеці, коли вона, їі права і свободи надійно захищені (забезпечені, гарантовані). Боднар О. Б. (2011) зауважує, що право на безпеку означає можливість користування соціальним благом; володіти ним означає користуватись благом - в іншому випадку воно не має ніякого сенсу.

Оскільки за напрямком професійної безпеки суддів наукові дослідження практично відсутні, поглянемо на дослідження за спорідненими напрямками.

Досліджуючи професійну безпеку працівників Національної поліції, Михайлова Ю. О. (2015) наголошує: «Для будь-якого підприємства, установи, організації стан безпеки її персоналу визнається одним із важливих критеріїв і показників ефективності та якісної роботи. Не стане винятком й Національна поліція, адже від рівня правової захищеності поліцейського, його особистої безпеки буде залежати якість та ефективність роботи всієї Національної поліції».

Вивчаючи професійну безпеку військовослужбовців Державної прикордонної служби України, Ковальська I. Е. (2011) формулює два вкрай важливі положення: по-перше стосовно того, що «діяльність персоналу ДПСУ є тим специфічним видом праці, що призводить до порушення його особистої безпеки»; по-друге - що «особиста безпека військовослужбовців ДПСУ за своєю структурою містить три тісно пов'язані компоненти: фізичний, психологічний і професійно етичний».
Достатньо цікаві 3 методологічної точки зору перспективи відкриваються у разі спроби поширення концепції кадрової безпеки на сферу організації роботи судів. Такий підхід може видатись дискусійним, адже у міжнародному науковому полі питання кадрової безпеки досліджуються передусім на базі підприємств і відносяться до сфери економічної науки, хоча питання, які піднімаються у таких дослідженнях мають безумовно правову природу. Приміром, Ковтиш О. П. (2015), грунтовно дослідивши питання кадрової безпеки доходить висновку щодо доцільності тлумачення кадрової безпеки «як підсистеми економічної безпеки підприємства, що покликана підтримувати стабільне функціонування і поступальний розвиток організації, досягнення поставлених цілей (стратегічних та тактичних) i результатів шляхом формування, постійного забезпечення та моніторингу оптимальних умов відтворення персоналу, нарощення його потенціалу як основи стійкості до загроз у контексті тісного взаємозв'язку із середовищем. $\mathrm{y}$ цьому випадку модифікації стосуватимуться передусім статусу державного службовця, а також особливостей антикорупційного законодавства, що застосовується у цій сфері. Схожі спроби за напрямком адаптації методології кадрового менеджменту здійснювались у вітчизняній юриспруденції. Зокрема, Оліфіренко Л. Д. та Віктор Т. М. (2015) наголосили, що реформування судової системи України передбачає впровадження ефективних методів адміністрування та вимагає переосмислення ролі кадрового менеджменту в органах судової влади, спрямованих на формування висококваліфікованого апарату суду 3 позицій підвищення вимог державного управління до забезпечення міжнародно-правових стандартів, а Чаку $€$ В. (2012) відзначив, що кадрове та 
матеріально-технічне забезпечення судів мають важливе значення для забезпечення ефективної організації та діяльності судових установ й, відтак, підтримання їх на належному рівні має бути першочерговим завданням державної політики.

У випадку зі спробою застосування такого підходу до сфери формування i розвитку суддівського корпусу методологічні обмеження посилюються у зв'язку з особливостями статусу судді.

Подібна міждисциплінарна адаптація методології 3 урахуванням обмеженості профільних досліджень за предметом забезпечення безпеки судової влади може стати сталим підгрунтям розвитку наукових поглядів за даним напрямком. 3 урахуванням практично повної відсутності комплексних досліджень безпеки суду та органів системи правосуддя вважаємо за можливе звернути увагу на концепцію організаційної безпеки, елементом якої, власне, виступає кадрова безпека організації.

Проаналізувавши низку джерел Суббот А. I. (2012) доходить висновку, що безпека організації - це стан такої діяльності організації, при якому відсутні або знаходяться в допустимих межах ризики фінансових, кадрових, виробничих втрат, забезпечується стабільність функціонування організації та діяльності їі працівників у різних умовах.

Голіков I. В. (2014) за результатами поглибленого дослідження безпеки організації виокремив низку її складових, зокрема, фінансову, інформаційну, соціально-економічну, інституційно-правову, технікотехнологічну, інтелектуально-кадрову, силову та екологічну. Бачимо, що у цілому такий підхід відповідає теоретичним основам забезпечення національної безпеки та безпеки судів. Як ми виявили у ході дослідження національної безпеки, домінуючі взорування про єдність її елементів та виокремлення окремих видів можуть бути перенесені і на рівень безпеки організації. За винятком порядку та значимості окремих складових, не бачимо жодних перешкод для їх застосування у якості класифікуючи чинників до діяльності з забезпечення безпеки судової влади. Зважаючи на те, що «екологія» тлумачиться як «взаємовідношення між організмом i оточуючим середовищем», екологічна безпека теж може вважатись одним 3 видів безпеки судової влади, особливо на тлі поширення вчення про сталий розвиток.

У цьому контексті, слід погодитись 3 тезою Каштеляна С. О. (2013) щодо того, що загальноприйняте штучне дроблення безпеки системи на окремі види і форми насправді є лише зручним методичним прийомом, способом моделювання реальних процесів, що дозволяє розглянути цю складну проблему у всій іiі різноманітності. На думку науковця, кожного об'єкта нескінченна кількість атрибутів. Звідси випливає, що і «видів безпеки» може бути нескінченна безліч. Але захист атрибута не може являти собою самоцінну задачу (так само, як атрибут $\epsilon$ тільки властивістю об'єкта, хоча й істотною), а цінним $\epsilon$ лише забезпечення безпечного існування самого носія цих властивостей. Ця гіпотеза підтверджується й міркуваннями Тихого В. П. (2016), котрий наголошує, що безпека виступає формою прояву своєї протилежності небезпеки, і окремо від предмета не існує; вона $\epsilon$ властивістю предмета, а не становить сам предмет.

\section{ВИСНОВКИ}

Сучасна теорія безпеки судової влади $\epsilon$ розрізненою. Відсутність єдиного методологічного орієнтиру провокує ситуацію некорельованого розвитку окремих елементів системи забезпечення безпеки судової влади. За 
результатами проведеного дослідження ми доходимо висновку, що для формування методичного базису забезпечення безпеки судової влади оптимальною основою слід вважати міжнародні стандарти правосуддя.

\section{References}

Bodnar, O. B. (2011). Poniattia ta zmist prava liudyny na bezpeku ta yoho spivvidnoshennia z sumizhnymy pravamy. Forum prava, $1 . \quad 88-93$. http://nbuv.gov.ua/UJRN/FP_index.htm_2 011_1_18

Chaku, Ye. V. (2012). Problemy kadrovoho ta materialno-tekhnichnoho zabezpechennia administratyvnoho sudochynstva. Pravo i suspilstvo, 2. 182186.

Council of Judges of Ukraine. (2018). Pro zakhody zabezpechennia bezpeky sudiv i suddiv, okhorony sudiv ta osib, kotri berut uchast $u$ zdiisnenni sudochynstva https://zakon.rada.gov.ua/rada/show/v00 65414-18\#Text

Holikov, I. V. (2014). Sutnist ta evoliutsiia poniattia ekonomichna bezpeka. Problemy ekonomiky, 1. 309-314.

Ihonin, R. V. (2010). Sudova militsiia Ukrainy $\mathrm{V}$ konteksti administratyvnopravovoi reformy. Advokat, 9. 43-48.

Ivanochko, I. B. (2015). Realizatsiia mizhnarodnykh standartiv shchodo statusu suddiv $\mathrm{u}$ khodi provedennia sudovopravovoi reformy v Ukraini. Pravo.ua, 1. 176-181.

Kashtelian, 0. (2013). Sutnist ta zmist poniattia "bezpeka" u konteksti zabezpechennia natsionalnoi bezpeky Ukrainy u prykordonnii sferi. Chest i zakon, 1. 17-21

Kavtysh, 0. P. (2015). Systemna pryroda kadrovoi bezpeky pidpryiemstva. Ekonomichnyi visnyk Natsionalnoho tekhnichnoho universytetu Ukrainy "Kyivskyi politekhnichnyi instytut", 12. 181189.

Kipcharskyi, O. M. (2020). Teoretykopravovi problemy derzhavnoho kontroliu za diialnistiu sluzhby sudovoi okhorony. Pravovi horyzonty, \#23. 78-82. http://www.doi.org/10.21272/legalhorizo ns.2020.i23.p78

Korniievskyi, O. (2008). Kontsept suspilnoi bezpeky: suchasnyi naukovoekspertnyi dyskurs. Ukrainska natsionalna ideia: realii ta perspektyvy rozvytku, 21 103-107

Koroied, O., Kresina, I. O., \& Prylutskyi, V. (2015). Kontseptsiia reformuvannia sudovoi vlady Ukrainy. Sudova apeliatsiia, 3. 6-34.

Kovalska, I. E. (2011). Osobysta bezpeka viiskovosluzhbovtsiv Derzhavnoi prykordonnoi sluzhby Ukrainy: sutnist, struktura ta sotsialno-psykholohichni chynnyky yii zabezpechennia. Visnyk Natsionalnoi akademii Derzhavnoi prykordonnoi sluzhby Ukrainy, 3. http://nbuv.gov.ua/UJRN/Vnadps_2011_3_ 18

Moskvych, L. M. (2009). Mizhnarodni standarty efektyvnosti sudovoi systemy ta yikh znachennia pid chas provedennia sudovoi reformy v Ukraini. Visnyk Akademii advokatury Ukrainy, 2. 151-157.

Mykhailova, Yu. O. (2015). Osnovni napriamy zabezpechennia bezpeky zhyttiediialnosti pratsivnykiv Natsionalnoi politsii. Naukovyi visnyk Uzhhorodskoho natsionalnoho universytetu: seriia: Pravo, 35, 2, 2. 156-157.

Olifirenko, L. D., \& Viktor, T. M. (2015). Rol kadrovoho menedzhmentu $\mathrm{V}$ mekhanizmi sudovoho administruvannia $\mathrm{v}$ umovakh reformuvannia sudovoi systemy Ukrainy. Problemy i perspektyvy ekonomiky ta upravlinnia, 3. 176-185

Osnovni pryntsypy nezalezhnosti sudovykh orhaniv. (1985). https://zakon.rada.gov.ua/laws/show/995 _201\#Text

Pchelin, V.B. (2017). Problemy pravookhoronnoho zabezpechennia sudochynstva v Ukraini. Naukovyi visnyk publichnoho ta pryvatnoho prava, 5, 1. 224229. 
Salenko, O. V. (2014). Mizhnarodni standarty u sferi sudoustroiu ta statusu suddiv, yikh zmist i klasyfikatsiia. Jurnalul juridic national: teorie şi practică. 3 (7) 2014. 263-269.

Shpenova, P. Yu. (2019). Aktualni pytannia shchodo struktury ta chyselnosti aparatu sudu. Sudova apeliatsiia. 2. 84-93.

Subbot, A.I. (2012). Teoretyko-pravovi osnovy bezpeky diialnosti orhnizatsii ta yii pratsivnykiv. Derzhava i pravo, 55. 258-263

Tykhyi, V. P. (2016). Bezpeka liudyny: poniattia, pravove zabezpechennia, znachennia, vydy. Visnyk Natsionalnoi akademii pravovykh nauk Ukrainy, 2. 31-46.

Vysnovok \#11 Konsultatyvnoi rady yevropeiskykh suddiv. (2008). https://court.gov.ua/userfiles/visn_11_20 08.pdf
Vysnovok \#14 Konsultatyvnoi rady yevropeiskykh suddiv. (2011). https://court.gov.ua/userfiles/R_14_2011_ 2011_11_9.pdf

Vysnovok \#8 Konsultatyvnoi rady yevropeiskykh suddiv. (2006). http://court.gov.ua/userfiles/visn_8_2006. pdf

Zahalna (Universalna) khartiia suddi. (1999). https://zakon.rada.gov.ua/laws/show/995 j63\#Text

Zuieva, I.I., \& Prystup, V.M. (2019). Orhanizatsiino-pravovi problemy stvorennia ta diialnosti sluzhby sudovoi okhorony v Ukraini. Yurydychnyi naukovyi elektronnyi zhurnal, \#3. http://www.lsej.org.ua/3_2019/63.pdf 


\title{
Management of socio-economic systems in Ukraine: European integration paradigm
}

\author{
Larisa Yankovska ${ }^{1}$
}

Received: 2021-03-11

Accepted: 2021-04-08

DOI: http://doi.org/10.46489/gpj.2021-1-1-3

\begin{abstract}
The theory and methodology of management of socio-economic systems are constantly evolving, reflecting the objective processes of departure from the Soviet, postSoviet and transitional paradigms of Ukrainian society. The next step is no less complex reform due to the integration of Ukraine into the European economic, social, legal, civilisational space. Today, Ukraine's European integration has become a national idea, a strategic vector of geopolitical development, which is a criterion for the success or failure of reforms in all areas of national economic governance. In this article, we examined the change in the socio-economic paradigm in connection with Ukraine's European integration development priority. We analysed the conditions for forming the European integration paradigm, explored the critical European values and the content of modern management of socio-economic systems. We have described approaches to assessing the effectiveness of socio-economic systems management at the national and regional levels. Considering the directions of European integration processes, we concluded that the European integration paradigm should become a methodological guideline for reforms in the management of socioeconomic systems.
\end{abstract}

Keywords: management of socio-economic systems, European integration, system, sustainable development, paradigm.

\footnotetext{
1 Larisa Yankovska, DSc, Professor, Honored Worker of Education of Ukraine, Chancellor, Lviv university of business and law, Kulparkivska, 99, 79021 Lviv, Ukraine, e-mail: larisalubp@gmail.com, ORCID: http://orcid.org/0000-0003-1855-0169
} 


\section{ВСТУП}

Теорія та методологія управління соціально-економічними системами безупинно розвивається, відбиваючи об'єктивні процеси відходу від радянської, пострадянської і перехідної парадигми становлення українського суспільства. На черзі не менш складна реформа, зумовлена інтеграцією України у європейський економічний, соціальний, правовий, цивілізаційний простір. Європейська інтеграція України на сьогоднішній день стала національною ідеєю, стратегічним вектором геополітичного розвитку, що $\epsilon$ критерієм успішності чи невдачі реформ у всіх сферах управління національною економікою. Таким чином, актуальною проблемою сучасності $€$ обгрунтування євроінтеграційних чинників, що впливають на управління соціальноекономічними системами в Україні.

у існуючих вітчизняних дослідженнях управління соціальноекономічними системами останні позиціонуються з точки зору перехідної економіки пострадянського періоду. Зі зміною стратегічного бачення розвитку національної економіки, що відбулося після Революції гідності, невирішеною частиною проблеми управління соціально-економічними системами $\epsilon$ врахування окремих євроінтеграційних чинників на різних управлінських рівнях - від держави до регіону. Цьому питанню присвячується дана стаття.

Метою статті $€$ обгрунтування євроінтеграційних чинників, що впливають на трансформацію підходів до управління соціально-економічними системами в Україні.

\section{РЕЗУЛЬТАТИ}

Великим здобутком i першим кроком у напрямі стирання кордонів та відновлення історичної справедливості стало уведення безвізового режиму України з Європейським союзом. Однак, це лише початок тривалого періоду реформ, у більшості своїй болючих, оскільки їх спільною концептуальною основою $\epsilon$ відсторонення від радянського минулого та перехід у якісно новий стан державотворення наближення до європейських стандартів.

Вкрай важливим $\epsilon$ для нас сьогодні не лише декларувати, а й поділяти європейські цінності, серед яких слід наголосити на повазі до демократичних принципів, верховенства права, доброго врядування, прав людини i основоположних свобод, у тому числі прав осіб, які належать до національних меншин, недискримінації осіб, які належать до меншин, i повазі до різноманітності, людської гідності та відданості принципам вільної ринкової економіки, які сприяють участі України в Європейських політиках. Посилення зв'язків між Європейським союзом та Україною базується на досягненні останньою принципів верховенства права, належного врядування, боротьби 3 корупцією, боротьби 3 різними формами транснаціональної організованої злочинності й тероризмом, сприяння сталому розвитку i ефективній багатосторонності.

Політична асоціація та економічна інтеграція України 3 Європейським Союзом залежатиме від прогресу в імплементації Угоди про асоціацію, а також від досягнень України в забезпеченні поваги до спільних цінностей і прогресу в наближенні з ЄС у політичній, економічній та правовій сферах.

Економічному та галузевому співробітництву України $3 \in \mathrm{C}$ присвячено окрему главу у Угоді про асоціацію. Серед основних напрямків співробітництва - енергетика, управління державними фінансами, охорона навколишнього середовища, інфраструктурні питання та багато інших, що можливо узагальнити, як реалізацію довгострокових цілей сталого розвитку. Не менш важливим $\epsilon$ i 
співробітництво у сфері науки та технологій.

Посилення

технологічного наукового та співробітництва України з ЄС має на меті як науковий розвиток як такий, так і зміцнення свого наукового потенціалу для вирішення національних та глобальних викликів. Досягнення прогресу в набутті наукових та технологічних знань, важливих для забезпечення сталого економічного розвитку забезпечується шляхом розвитку дослідних потужностей та людського потенціалу. Накопичення та обмін науковою інформацією сприяють підвищенню конкурентоспроможності сторін шляхом розширення можливостей їх економіки щодо набуття та використання знань для комерціалізації нових продуктів та послуг. Від розвитку наукового потенціалу залежить дотримання глобальної відповідальності та зобов'язань у таких сферах, як охорона здоров'я, захист навколишнього середовища, зокрема зміна клімату, та інші глобальні виклики.

Автори Національної доповіді «Соціально-економічний потенціал сталого розвитку України та ії̈ регіонів» $(2014,7)$ наголошують, що перехід національного господарства України на модель сталого розвитку значною мірою залежить від наявного потенціалу розширеного відтворення ресурсної бази соціально-економічного піднесення на новій інституціональній і технологічній основі. Досвід передових країн та наслідки структурної i системної перебудови більшості сегментів національного господарства свідчать, що реальні зрушення в напрямі формування передумов сталого розвитку як держави в цілому, так і окремих регіонів можливі лише за умови нарощення не лише виробничого, а й природно-ресурсного, демографічного, науково-технічного, рекреаційного, інформаційного та соціально-культурного потенціалу. Тобто, мова йде про всі складові соціально-економічного потенціалу, а також людський фактор та інституціональні зміни в системі економічних відносин при виборі пріоритетів переходу національного та регіональних господарських комплексів на модель сталого розвитку. Підготовка цієї національної доповіді зумовлена необхідністю врахування численних екзогенних та більшою мірою ендогенних чинників соціальноекономічного потенціалу сталого розвитку у зв'язку з інституціональним закріпленням євроінтеграційних прагнень українського народу.

Щодо визначення поняття соціально-економічної системи можемо навести міркування Т. В. Рудакової (2008), котра відзначає, що соціальноекономічну політику регіону можна визначити як забезпечення життєдіяльності людей на певній території. Задоволення їх життєвих можливостей можливо при двох обставинах: при наявності необхідної сукупності матеріальних та духовних благ та при можливості цими благами користуватися. Названі блага формуються в процесі суспільного виробництва, яке $\epsilon$ основою для створення необхідних життєвих благ, з одного боку, та отриманням доходів від створення цих благ, 3 другого боку. Соціально-економічну систему можна характеризувати як системи, що моделюють господарсько-економічну діяльність у сукупності з регулюванням соціальної сфери суспільства певного регіону.

Е. В. Щепанський (2009) наголошує, що здійснення соціально-економічних реформ в Україні, спрямованих на забезпечення стабільних умов життя та підтримку належного рівня добробуту населення, як і адаптація с промислового виробництва до загальносвітових тенденцій розвитку, пов'язаних із к формуванням 
постіндустріальної

економіки, вимагають посиленої уваги до процесу здійснення структурних перетворень в регіональному господарському комплексі. Саме 3 структурною політикою пов'язаний комплекс специфічних завдань періоду перетворень - від формування сучасного ринкового середовища до подолання екстенсивного типу розвитку країни та іï регіонів, усунення численних деформацій їі структури. Реалізація зазначених цілей вимагає розробки відповідного механізму управління соціально-економічним розвитком. О. Половцев (2010) зазначає, що функціонування соціальноекономічних систем являє собою складний процес, зумовлений великою кількістю різноманітних факторів. На сьогодні дуже незначна частина завдань, що розв'язуються в процесі державного управління, мають аналітичну підтримку у вигляді моделей керованих процесів та систем. Система державного управління, на думку науковця, $€$ переплетінням множини структур та процесів різної природи, кожен 3 яких функціонує у взаємодії та тісній інтеграції з іншими процесами та системами. Прийняття задовільних рішень 3 прогнозованою ефективністю неможливе без аналітичної підтримки та передбачає використання більш-менш формалізованої моделі керованого об'єкта. Модель процесу прийняття рішення в галузі державного управління відображає особливості процедур підготовки та вибору рішень, участь у них адміністрації відповідних рівнів, зв'язок ресурсів та зовнішніх умов із станом керованої соціально-економічної системи та результатами впровадження рішень. 3 цього приводу О. Е. Кац (2012) підкреслює, що державне управління соціально-економічними системами в ринкових умовах неможливе без аналізу дії чинників зовнішньої і внутрішньої середовища, оскільки будь-яка система є відкритою, працюючою в нестабільному ринковому середовищі. Це означає, що система має зв'язок із зовнішнім середовищем, що реалізовується за допомогою взаємного обміну різними ресурсами (природними, матеріальними, технічними, енергетичними, людськими, інформаційними, фінансовими).

В умовах децентралізації все більше повноважень щодо управління соціально-економічними системами відходить на рівень регіонів.

C. М. Юрійчук (2011) з цього приводу відзначає, що на сучасному етапі соціально-економічного розвитку регіонів дослідження регіонального управління $\epsilon$ складною комплексною системою і потребує багатоаспектного підходу 3 застосуванням теорії наукового управління. Науковець підкреслює, що соціально-економічний розвиток регіону - це цілісна система закономірностей, зв'язків і пропорцій здійснення відтворювальних процесів суб'єкта ми господарської діяльності різних форм власності на адміністративно окресленій території.

Як зауважує С. М. Юрійчук (2011), соціально-економічний розвиток регіону, з одного боку, - об'єктивний процес, що відбувається під впливом історичних, географічних, ресурсних, демографічних та інших факторів. 3 другого боку, - це суб'єктивний процес, що здійснюється під впливом управлінських заходів 3 боку регіональної адміністрації адміністрації державного рівня.

На рівні управління соціальноекономічним розвитком систем окремих закладів, установ, підприємств актуальною $є$ проблема напрацювання стратегії розвитку в умовах непередбачуваних подій, передусім кризового характеру. 3 цього приводу 0. P. Савченко (2012) зауважує, що основними властивостями сучасного 
бізнес-середовища,

B

якому

функціонують вітчизняні організації, $\epsilon$ мінливість, невизначеність i нестабільність. Такі умови вимагають від керівників організацій здатності інтуїтивно відчувати проблеми ринкового господарювання, професійно підходити до їх подолання (уникнення, якщо таке можливо, або прийняття шляхом ефективного управління). Для забезпечення останнього керівники повинні мати високопрофесійні навички, вміння та досвід, повинні бути обізнаними 3 чинниками, які притаманні сфері їх господарювання, ситуативними механізмами управління тощо.

Оцінка ефективності управління соціально-економічним розвитком може здійснюватись на основі низки методик. Серед них, О. Е. Кац (2012) пропонує виділяти такі, що пов'язані, перш за все, з контролем реалізації місії і бачення глобальних і базових стратегій. Вирішення цих завдань, зауважує науковець, може бути досягнуте на основі використання таких наукових методів, як діагностичний аналіз, аналіз основних чинників зовнішньої середовища на основі комплексного (соціального, технічного, економічного і політичного, природного) STEP-аналізу для виявлення можливостей і загроз; аналіз сильних і слабких сторін внутрішнього середовища соціальноекономічної системи; спільний матричний аналіз сильних, слабких сторін можливостей і загроз (SWOTаналіз); аналіз стратегічного потенціалу, конкурентних переваг, умов функціонування i привабливості на основі спеціальної розробленої номограми 3 метою виявлення глобальної стратегії для соціальноекономічної системи.

Т. В. Рудакова (2008) наголошує, що глобалізація економіки $\epsilon$ багатогранним процесом, основними рушійними силами якого $є$ технологічний прогрес, розвиток міжнародної інфраструктури, зміни в інформаційній технології та лібералізація торгівлі та міжнародних зв'язків. Ці фактори, як показує практика економічного розвитку усіх країн світу, мають безпосередній вплив на соціальний та економічний розвиток. Перш за все це позначається на зростанні обсягів торгівлі товарами та послугами. Важливим наслідком глобалізації стала інтенсифікація потоків прямих іноземних інвестицій, обсяги яких $\epsilon$ особливо динамічними. Технічні та технологічні зміни, що $\epsilon$ необхідною передумовою розвитку людини, спричиняють трансграничний рух капіталу, виробничих потужностей, товарів та послуг, переміщення робочої сили. Такі процеси викликають зміни в соціальній сфері, що призводить до переміщення та скорочення робочих місць, девальвації традиційних спеціальностей та потреби нової кваліфікації.

He менш важливим $\epsilon$ питання критерію економічної безпеки в управлінні соціально-економічним розвитком на усіх рівнях. 0. Д. Гудзинський та С. М. Судомир (2014) акцентують на тому, що у сучасних умовах здійснення глобалізаційних та інтеграційних процесів ускладнюються економічні зв'язки між суб'єктами діяльності горизонтально вертикального спрямування, скорочується часовий лаг життєвих циклів дій систем і механізмів підтримання підприємницьких структур в стані запрограмованого функціонування згідно за часовими, кількісними і якісними параметрами. Вибір точки проведення змін в соціально - економічних системах $\epsilon$ базовою i методологічною основою забезпечення їх динамічного, стратегічно - конкурентного розвитку та економічної безпеки.

Окремо слід наголосити на значенні європейської інтеграції для галузі освіти в Україні. Співробітництво в галузі освіти, навчання та молодіжної 
політики має на меті покращення взаєморозуміння, активізації міжкультурного діалогу та посилення знань щодо відповідних культур. Найважливішими напрямками євроінтеграційних процесів у сфері вищої освіти $€$ такі, як

а) реформування та модернізації систем вищої освіти;

b) сприяння зближенню у сфері вищої освіти, яке відбувається в рамках Болонського процесу;

c) підвищення якості та важливості вищої освіти;

d) поглиблення співробітництва між вищими навчальними закладами;

е) розширення можливостей вищих навчальних закладів;

f) активізації мобільності студентів та викладачів;

g) увага приділятиметься співробітництву в галузі освіти з метою спрощення доступу до отримання вищої освіти.

\section{ВИСНОВКИ}

Таким чином, на основі проведеного дослідження встановлено, що євроінтеграція України за умов успішного проходження усіх етапів цього процесу, $є$ безумовним чинником процвітання нашої держави. Проте до цього моменту існує безліч викликів в реформуванні управління соціальноекономічними системами різних рівнів, що відкриє для Україні перспективи повноцінного членства у Європейському Союзі.

\section{References}

Hudzynskyi, O. D., \& Sudomyr, S. M. (2014). Ryzyky ta ekonomichna bezpeka sotsialno-ekonomichnykh system. Zbirnyk naukovykh prats Tavriiskoho derzhavnoho ahrotekhnolohichnoho

(ekonomichni nauky), 2.35-37

Kats, O.A. (2012). Derzhavne rehuliuvannia ta kontrol rozvytku i funktsionuvannia sotsialnoekonomichnykh system riznykh rivniv. Upravlinnia proektamy ta rozvytok vyrobnytstva, 3 (43). 114- 117

Libanova, E. M., \& Khvesyk, M. A. (Red.). (2014). Sotsialno-ekonomichnyi potentsial staloho rozvytku Ukrainy ta yii rehioniv: Natsionalna dopovid. DU IEPSR NAN Ukrainy.

Polovtsev, 0. (2010). Metody modeliuvannia dynamiky sotsialnoekonomichnykh system. Visnyk Natsionalnoi akademii derzhavnoho upravlinnia pry Prezydentovi Ukrainy, 1. 105-111

Rudakova, T.V. (2008). Metodolohichni pryntsypy rozghliadu sotsialnoekonomichnoi systemy rehionu $\mathrm{v}$ period transformatsii pidsystem suspilstva. Ekon.mat. modeliuvannia sots.-ekon. system, 13. 186-192.

Savchenko, O. R. (2012). Upravlinnia zminamy $\mathrm{V}$ suchasnykh sotsialnoekonomichnykh systemakh. Aktualni problemy ekonomiky, 3. 19-24

Shchepanskyi, E. V. (2009). Formy ta metody upravlinnia sotsialnoekonomichnym rozvytkom: teoretychnyi aspekt. Universytetski naukovi zapysky, 3. 273-279

Yuriichuk, S. M. (2011). Osoblyvosti upravlinnia sotsialno-ekonomichnym rozvytkom rehioniv $\mathrm{u}$ suchasnykh umovakh. Investytsii: praktyka ta dosvid, 6. 52-53 


\title{
Problems and prospects of Ukrainian Advocacy development: Euro-integration discourse
}

\author{
Rostyslav Sopilnyk ${ }^{1}$, Yurii Semchuk ${ }^{2}$
}

Received: 2021-03-05

Accepted: 2021-04-10

DOI: http://doi.org/10.46489/gpj.2021-1-1-4

\begin{abstract}
European integration is now one of the central issues of politics, economics, law, and sociology. Changes in the legal consciousness of citizens, the turn of the political and legal situation that occurred as a result of the Revolution of Dignity led to the actualisation of fundamentally new requirements for the functioning of legal institutions. In this article, we explored the legal profession of Ukraine in the framework of European integration transformations. We have explored the theoretical basis of the processes of globalisation and European integration, which have a significant impact on legal reform in Ukraine. In particular, we have established the main models of European integration and the features of the European integration paradigm. We compared the current development goals of the Bar of Ukraine and the requirements that arise in connection with the Euro-integration discourse. This article can help elaborate a Ukrainian Advocacy development strategy in the Eurointegration discourse.
\end{abstract}

Keywords: advocacy of Ukraine, globalisation, European integration, models of European integration, legal reform in Ukraine.

\footnotetext{
${ }^{1}$ Rostyslav Sopilnyk, D.Sc. (Law), Professor, Professor of the Department of Judiciary, Prosecution and Advocacy, Lviv University of Business and Law, 99 Kulparkivska Str., Lviv, 79021, Ukraine, rostyslav.sopilnyk@ukr.net, ORCID: https://orcid.org/0000-0001-9942-6682

2 Yurii Semchuk, PhD, Assosiated Professor of the Department of Judiciary, Prosecution and Advocacy, Lviv University of Business and Law, 99 Kulparkivska Str., Lviv, 79021, Ukraine, ORCID: https://orcid.org/00000002-2829-0834
} 


\section{ВСТУП}

Питання розвитку інституту адвокатури, його реформування та приведення у відповідність до європейських стандартів неодноразово піднімалось у сучасних наукових дослідженнях та при обговоренні змін до профільного Закону. Питання глобалізації, євроінтеграції та розвитку адвокатури досліджували Абашидзе А. Х., Арутюнян Г.Г., Бліщенко В. И., Вільчик Т. Б., Дудаш Т. І., Кашкін С. Ю., Коваленко Є. О., Прилуцький С. В., Сталовєров В.М., Тихомиров Ю. А., Шкребець Є. У даній статті пропонується поглиблене дослідження впливу євроінтеграційної парадигми правової реформи на розвиток адвокатури.

Метою статті $\epsilon$ обгрунтування євроінтеграційного вектору розвитку адвокатури України.

\section{РЕЗУЛЬТАТИ}

Європейська інтеграція нині $\epsilon$ одним із центральних питань політики, економіки, права, соціології. Зміни у правосвідомості громадян, перелом політико-правової ситуації, що стався унаслідок Революції Гідності обумовили актуалізацію принципово нових вимог до функціонування правових інститутів.

С. Ю. Кашкін (2012) наголошує 3 приводу взаємовпливів процесів глобалізації і інтеграції у правовому вимірі, що процеси інтеграції та глобалізації мають велике значення для гармонізації економічних, політичних, культурних, ідеологічних та інших факторів, під впливом яких функціонує право. Вони впливають і на міжнародне, i на конституційне право, а також на будь-яку галузь законодавства, створюючи базу загальних тенденцій розвитку сучасного права.

Розглядаючи глобалізацію на європейському рівні Г.Г. Арутюнян (2004) наголошує на тенденціях, що впливають на систематизацію принципів правової демократичної держави, домінацію демократичних конституційних цінностей; визначають обмеження влади, розсіювання політичних, економічних i адміністративних сил за одночасного зміцнення гарантій та розширення можливостей інститутів самоуправління.

Ю. А. Тихомиров (2004) наголошує на наступній тенденції. Остання третина XX i початок XXI століть характеризуються тенденцією посиленого взаємопроникнення різних правових норм. 3 одного боку, у міжнародному праві i особливо у правових системах міжнародних об'єднань зростає питома вага норм, що «прийшли» 3 національного права. Держави гостріше відчувають потребу в забезпеченні захисті національних інститутів за допомогою механізму міжнародно-правового регулювання. Норми про права людини і громадянина, про парламентські, муніципальні і судові інститути «переміщуються» та набувають образ і статус міжнародноправових принципів, інститутів і норм. 3 іншого боку, у системах національного права все більшою стає питома вага схвалених міжнародних норм такого виду. У новому концентрованому вигляді вони як би повертаються в національне право, зливаючись 3 ним та збагачуючи його. Такі міжнародні норми стають правотвірним і оціночним фактором для відповідних національних інститутів і норм.

Поняття

євроінтеграційної парадигми $\epsilon \quad$ концептуально детермінованим розумінням змісту процесів євроінтеграції, їх теоретичного та методологічного підгрунтя.

Європейська інтеграція осмислюється крізь призму різних моделей, що базуються на векторах розвитку поглиблення та розширення. До основних моделей належать (Dudash T. I., 2013):

a) одночасний розвиток багатьох організацій - забезпечення розвитку 
через системне удосконалення та співпрацю європейських організацій, якот Рада Європи, ОБСЄ, ЦЄІ та ін.;

б) модель часткового членства участь асоційованих держав у певних заходах, що переважно здійснюються міжнародними організаціями на засадах інтеграції у довгостроковій перспективі;

в) модель «гнучкої Європи» базується на принципах вільного вибору міри участі держави $\mathrm{y}$ інтеграційних проектах, що обирається у відповідності до національних інтересів; модель відображає ідею неоднакового методу інтеграції, який дає змогу країнам-членам обирати стратегії;

г) модель «Європа концентричних кіл - передбачає наявність трьох різною мірою інтегрованих кіл держав: а) асоційовані з ЄС (зовнішнє коло); б) усі країни ЄС (середнє коло); в) держав, готові до тіснішої інтеграції в окремих областях (ядро).

Слід відзначити, що євроінтеграція України $є$ одним з конкретних проявів процесу глобалізації, котрий охопив світ у двадцятому столітті та у різних формах продовжує визначати національну політику багатьох країн. В. I. Бліщенко (2004) підкреслює, що феномен глобалізації $\epsilon$ одним із найбільш вагомих факторів, що визначає основи розвитку цивілізації та усіх країн світу на зламі XX та XXI століть. Глобалізація, за переконанням науковця, $\epsilon$ найвищим рівнем інтернаціоналізації суспільного життя, що характеризується пріоритетом міжнародних, глобальних чинників економічного, політичного, етнічного, релігійного, військового та екологічного розвитку над відповідними чинниками національного та регіонального рівнів.

А. Х. Абашидзе (2004) наголошує, що людство вступило в стадію глобалізації, яка набула незворотного характеру, утім до кінця неосмисленими залишаються питання сумісності глобалізації, економічних і соціальних реформ та прав людини. Г.Г. Арутюнян (2004) виокремлює низку значимих тенденцій, котрі характеризують сучасні процеси глобалізації:

а) досягнення демократичним розвитком у міжнародному плані певних якісних меж, що вимагає нового рівня та якості системної гармонійності і стійкості для подолання конфлікту між пріоритетами сьогодення та майбутнього;

б) наявність суперечностей між встановленням принципів правової демократії у внутрішньодержавних відносинах та диктатом сили у міжнародних відносинах;

в) глобалізація створила якісно нову ситуацію суспільної інтеграції, коли формуються міжнародні спільноти, що не мали прецедентів та висувається ідея наддержавної конституції;

г) загострення суперечностей між універсалізмом та національними особливостями, зокрема поява ціннісносистемних конфліктів у національноорієнтованих та особистісноорієнтованих суспільно-державних системах;

д) суттєвої зміни зазнають місце та роль міжнародного права у правовій системі; паралельно 3 інтернаціоналізацією права і небувалим розширенням масштабів, а також сфери впливу принципів і норм міжнародного права, відмінності традиційних правових систем стають все більш відносними;

е) одночасно значна кількість країн опинилась в зоні невизначеності, обумовленій системною перебудовою; неминучим процесом стало формування нової системи цінностей та вирішення проблем суспільного розвитку та ін.

С. В. Прилуцький (2015) підкреслює: Вже сьогодні маємо негативні наслідки безсистемного підходу, оскільки не тільки теоретики «ламають списи» у 
наукових дискусіях, а й, що найгірше механізм правосуддя та його юридична практика заганяється у глухий кут колізій вітчизняних законодавчих «новел». На цьому тлі у процесі нових реформаційних перетворень перебуває судова система, система кримінальної юстиції та правозахисту. Останні напрямки органічно включаються $\mathrm{y}$ спільні політики ЄC («сукупність нормативно-правових актів $€ C$, принципів і методів їх реалізації, які спільно впроваджуються інституціями Євросоюзу та державами-членами 3 метою досягнення визначених цілей і завдань політики») у сфері внутрішніх справ i юстиції (простір свободи, безпеки i правосуддя). Згідно Маахстрихтського договору, створення єдиної політики у цій сфері мало стати одним 3 пріоритетних i фундаментальних напрямків інтеграції європейських країн. Зміст спільної політики у сфері внутрішніх справ і юстиції полягає у формуванні сукупності правових та організаційних форм співробітництва правоохоронних і судових органів $€$, спрямованих на взаємодію в рамках спільних дій щодо притулку та імміграції, судового співробітництва і цивільних і кримінальних справах, а також поліцейського співробітництва з метою протидії транснаціональній злочинності (Dudash T. I., 2013).

Парадигма євроінтеграції включає такі елементи (Kovalenko Ye. O., 2008):

- формування знань про природу та сутність європейської інтеграції, специфіку функціонування $\epsilon C$;

- подолання психологічного пострадянського бар'єру суспільної думки стосовно нової системи Європейських координат й інтеграційних перспектив;

- створення проєвропейської більшості в суспільстві;
- забезпечення необхідних знань та навичок щодо розуміння цілей інтеграції i $\in C$ державними службовцями;

- всебічна підтримка політики уряду українським суспільством;

- набуття знань про ЄС та виховання молодих людей у дусі спільних європейських цінностей та ідеалів;

- всебічне інформування широкого кола громадськості з питань інтеграції.

Вільчик Т. Б. (2015) наголошує, що однією 3 умов інтеграції України до Європейського Союзу $є$ побудова такої системи адвокатури та створення законодавства щодо іiї організації i діяльності, норми якого відтворювали б модель демократичного правового інституту адвокатури, оскільки лише за умови належного функціонування цього інституту можливий розвиток демократії та верховенства права, що, у свою чергу, $\epsilon$ одним із головних критеріїв набуття Україною членства у Європейському Союзі. Євроінтеграційні прагнення України потребують узгодження системи правових норм України та $Є C$, зокрема, в сфері прав людини. Сталовєров В.М. (2017) акцентує на тому, що ратифікація угоди про асоціацію з Європейським Союзом засвідчила вибір Україною європейської системи цінностей та стандартів захисту прав людини, додержання яких на практиці можливе за умови реалізації принципу верховенства права, забезпечення кожному права на справедливий судовий розгляд незалежним та неупередженим судом, а також ефективного виконання своїх функцій суміжними правовими інститутами і перш за все адвокатурою України. Однією з умов досягнення членства в Європейському Союзі $\epsilon$ побудова такої системи адвокатури, яка відповідала б новим суспільнополітичним i економічним реаліям, 
розроблення законодавства, норми якого відтворювали б модель європейського інституту адвокатури.

$€$. Шкребець (2016) відзначає, що сучасне адміністративно-правове забезпечення адвокатури розвивається в складних політичних, економічних та навіть культурних умовах. Так, уся правова система перебуває під пильною увагою громадськості, міжнародних спостерігачів та взагалі всієї світової спільноти. Повноцінне входження України до Європейського Союзу потребує імплементації європейського законодавства до вітчизняного правового поля, а дотримання прав i свобод людини i громадянина $\epsilon$ невід'ємною частиною цього процесу. На цьому полі адвокатура повинна стати прикладом для всього суспільства. Роль адвокатури повинна бути посилена обов'язковою участю адвокатів в ухваленні та узгодженні законопроектів, які стосуються захисту прав громадян.

У Стратегії розвитку Національної асоціації адвокатів України (2015) визначено 4 Стратегічні цілі: зробити НААУ сильною, згуртованою та авторитетною організацією в Україні та світі; забезпечити активну участь їі членів у конституційному процесі та втіленні конституційних змін у чинне законодавство;

удосконалити процедури професійної підготовки та розвитку адвокатів; покращити ефективність системи комунікацій 3 усіма суб'єктами та учасниками правової реформи в Україні.

Зазначені цілі деталізовано у вигляді низки задач, серед яких удосконалити роботу системи органів адвокатського самоврядування в Україні та сприяти більш активному залученню адвокатів до їх роботи на національному та регіональному рівнях; підвищити вимоги щодо здійснення адвокатської діяльності, зокрема посилити професійні та моральноетичні вимоги до осіб, які мають намір отримати статус адвоката, та до дисциплінарного контролю професії; спростити процедуру доступу громадян до безоплатної правової допомоги; удосконалити систему правового регулювання професійних прав та обов'язків адвокатів, забезпечити гарантії здійснення адвокатської діяльності. запровадити ефективні механізми притягнення до відповідальності посадових осіб за порушення гарантій незалежності адвокатів; якісно змінити систему професійного розвитку та удосконалити процедуру підвищення кваліфікації адвокатів; активно розвивати співпрацю 3 міжнародними професійними організаціями адвокатів для запозичення та запровадження їх передового досвіду; удосконалити систему оподаткування адвокатської діяльності (Stratehiia rozvytku Natsionalnoi asotsiatsii advokativ Ukrainy, 2015).

Актуалізація $\quad$ євроінтеграційної парадигми у вимірі юриспруденції зумовила утворення нової доктрини інтеграційного права. У його основі розуміння інтеграції як динамічного руху до об'єднання розрізнених елементів у нову, більшу і досконалішу цілісну систему, що відзначається наявністю на сучасному етапі трьох базових компонентів: ï прагнення до вдосконалення, постійну мінливість цього динамічного процесу i його спрямованість на створення завершеної, цілісної системи (Kashkin S. Yu., 2012).

\section{вИСНовкИ}

Отже, підсумовуючи проведене дослідження, відзначимо наступне. Євроінтеграційна парадигма визначає динаміку правової реформи в Україні на найближчі роки. Євроінтеграційні прагнення обумовлюють необхідність суттєвих перетворень у різних сферах права, у тому числі й стосовно організаційно-правового забезпечення 
діяльності і розвитку адвокатури України.

Надалі доцільним $€$ дослідження концептуальних передумов досягнення незалежності адвокатури в умовах євроінтеграції України.

\section{References}

Abashydze A. Kh. (2004). Novye tendentsyy $\mathrm{v}$ normotvorcheskoi deiatelnosty $00 \mathrm{~N} v$ oblasty zashchytы prav cheloveka. Hlobalyzatsyia, hosudarstvo, pravo. $21-26$.

Arutiunian H.H. (2004). Pravovaia hlobalyzatsyia y nekotorye tendentsyy razvytyia konstytutsyonalyzma. Hlobalyzatsyia, hosudarstvo, pravo. 27 - 33.

Blyshchenko V. Y. (2004). Hlobalyzatsyia y mezhdunarodnoe pravo. Hlobalyzatsyia, hosudarstvo, pravo. 17 - 20.

Dudash T. I. (2013). Praktyka Yevropeiskoho sudu $z$ prav liudyny. K. Alerta, $368 \mathrm{~s}$.

Kashkin S. Yu. (2012). Intehratsiine pravo yak kontsentrovane vyrazhennia porivnialnoho prava: poniattia, tendentsii ta etapy rozvytku. Porivnialne pravoznavstvo, 3-4. 306-315.

Kovalenko Ye. O. (2008). Kontseptualno-metodolohichni zasady analizu yevrointehratsiinoi polityky. Humanitarnyi visnyk Zaporizkoi derzhavnoi inzhenernoi akademii, 32. 210-219.

Prylutskyi S. V. (2015). Sudove pravo yak kontseptualna osnova sudovoi vlady Ukrainy. Pravo Ukrainy, 3. 26 - 41.

Shkrebets Ye. (2016). Shliakhy vdoskonalennia administratyvnoho zakonodavstva shchodo zabezpechennia diialnosti advokatury v Ukraini. Pidpryiemnytstvo, hospodarstvo i pravo, 2. 122-127

Stalovierov V.M. (2017). Problemy reformuvannia zakonodavstva pro advokaturu ta advokatsku. Molodyi vchenyi, 5.1 (45.1). 127-132.

Stratehiia rozvytku Natsionalnoi asotsiatsii advokativ Ukrainy (2015). URL: http://unba.org.ua/assets/uploads/files/st rategiya-rozvitku-naau-do-2020-roku.pdf

Tykhomyrov Yu. A. (2004). Ynternatsyonalyzatsyia natsyonalnoho prava. Hlobalyzatsyia, hosudarstvo, pravo. $167-174$.

Vilchyk T. B. (2015). Instytut advokatury Ukrainy: novi pidkhody ta tendentsii rozvytku. Naukovyi visnyk Mizhnarodnoho humanitarnoho universytetu. Seriia: Yurysprudentsiia, 16(1). $25-28$ 


\title{
Prerequisites for the development of a clear social responsibility concept
}

\author{
Andrii Yevstakhevych', Iren Karen Von-Nahy²
}

Received: 2021-03-12

Accepted: 2021-04-14

DOI: http://doi.org/10.46489/gpj.2021-1-1-5

\begin{abstract}
The concept of social responsibility has a broad interpretation due to different approaches to forming its concept, the definition of fundamental principles, methods, and ways to ensure the expected results. The term "social responsibility" should be used considering the current state of research in this area and the discourse formed under the influence of the integration of foreign experience in ensuring social responsibility and the practice of Ukrainian enterprises in this area. We considered the history of formation and development of the concept of social responsibility of enterprises in Ukraine. We noted that the approaches to the formation of the concept of social responsibility differ significantly. We emphasized that the development of a transparent concept of social responsibility should be based on the factors, content and models of this activity. We concluded that due to the crisis in the economy and society in Ukraine, the concept of social responsibility had acquired a unique regional shape. This gave rise to the lack of a unified state policy of social responsibility of business, unsystematic measures of enterprises to implement the introductory provisions, the lack of a systematic approach to the transformation of social responsibility management.
\end{abstract}

Keywords: social responsibility, theory of social responsibility, standards of social responsibility, factors of social responsibility.

\footnotetext{
${ }^{1}$ Andrii Yevstakhevych, PhD, lecturer, Department of Business Economics and Information Technology, Lviv university of business and law, Kulparkivska, 99, 79021 Lviv, Ukraine, e-mail: yevstakhevych10@meta.ua, ORCID: https://orcid.org/0000-0003-1058-5359

${ }^{2}$ Iren Karen Von-Nahy, lecturer, Department of Business Economics and Information Technology, Lviv university of business and law, Kulparkivska, 99, 79021 Lviv, Ukraine, ORCID: https://orcid.org/0000-0002-2748-7766
} 


\section{ВСТУП}

У зв'язку 3 об'єктивними чинниками, що виникають як наслідок переходу до ринкової економіки, інтереси підприємств та держави, громад, громадян вимагають узгодження. Після здобуття незалежності, Україна поступово трансформувалась у соціальноорієнтовану державу 3 ринковою економікою. Утім, перманентні кризові явища в економіці та соціальній сфері спровокували загострення конфлікту між інтересами підприємств, держави і суспільства. У короткостроковому вимірі, намагаючись максимізувати прибутки підприємства нерідко стали діяти всупереч інтересам держави (наприклад, виходячи у тіньовий сектор економіки, завдаючи своїми діями шкоди екологічній ситуації тощо), ще частіше - суспільства (порушуючи зобов'язання перед працівниками, ігноруючи вимоги громадськості щодо своєї діяльності, завдаючи інших прямих чи непрямих збитків оточуючому середовищу тощо). $\mathrm{y}$ довгостроковому вимірі така стратегія діяльності підприємств не може вважатись продуктивною, оскільки суперечить основоположному діалектичному принципу взаємозв'язку та взаємообумовленості. Вирішенням цієї проблеми $\epsilon$ реалізація концепції соціальної відповідальності підприємств, що пройшла тривалий шлях розвитку та широко апробована у розвинених країнах.

Концепція

відповідальності розвивалась протягом тривалого часу. На сьогоднішній день виокремилось досить багато теоретичних підходів до розуміння соціальної відповідальності. Питанням соціальної відповідальності присвячено, праці таких вчених, як Баюра Д., Брич В. Я., Головінов О. М., Градюк Н. М., Дєліні М. М., Колот А. М., Лазоренко Л. В., Марущак Н. В.,
Селіверстова Л., Стойка В. О., Чала Ю. В. та ін.

Доповнюючи результати, одержані згаданими авторами, у даному дослідженні маємо на меті з'ясувати актуальний стан розвитку концепції соціальної відповідальності для вітчизняних реалій.

Відтак, метою статті є виявлення особливостей сучасного трактування концепції соціальної відповідальності підприємств в Україні.

\section{РЕЗУЛЬТАТИ}

Поняття соціальної відповідальності має широке тлумачення, що обумовлюється різними підходами до формування їі концепції, визначення основних принципів, методів та шляхів забезпечення, очікуваних результатів. Оперувати терміном «соціальна відповідальність» слід 3 урахуванням актуального стану досліджень у цій сфері та дискурсу, сформованого під впливом інтеграції іноземного досвіду забезпечення соціальної відповідальності та практики українських підприємств у цій сфері.

Досліджуючи проблематику соціальної відповідальності, Ю.В. Чала (2014) зазначає, що основою ефективної ринкової економіки та демократичного суспільства $є$ безперервний діалог між урядом, бізнесом і громадським суспільством. Соціальна відповідальність бізнесу $\epsilon$ одним із ключових факторів для побудови такого діалогу. Ступінь розвитку соціальної відповідальності бізнесу відображає рівень партнерства між компаніями, урядовими структурами та головними дійовими особами громадянського суспільства щодо вирішення соціальних проблем i прискоренню розвитку суспільства. Брич В.Я. та Смачило I. I. (2014) наголошують, що економіка України на сучасному етапі характеризується трансформаційними процесами, через перебіг яких постійно змінюються умови функціонування 
підприємств. Цілеспрямований та безперервний розвиток підприємств, який підтримує рівень економічних, виробничих, технічних, соціальних показників у межах, визначених впливом зовнішнього та внутрішнього середовищ, потребує врахування інтересів споживачів, підлеглих, суспільства, партнерів, працівників, постачальників, менеджерів, акціонерів. Тому соціальна відповідальність $\epsilon$ стратегічним напрямком соціального розвитку підприємств. На думку Лазоренко Л. В. (2013), соціальна відповідальність підприємств у сучасних умовах $\epsilon$ невід'ємною складовою їх ефективної діяльності. Соціально відповідальні організації здійснюють вагомий внесок в розвиток суспільства, адже на власному прикладі демонструють ставлення до свого персоналу, навколишнього середовища, результатів своєї діяльності та країни в цілому. 3 іншого боку, висока корпоративна культура та відповідальність підприємств сприяє підвищенню їх фінансових можливостей, тому що такі організації мають досить високу репутацію як в Україні, так i за кордоном, що $\epsilon$ причиною успішного ведення бізнесу, підвищення конкурентоспроможності та економічної ефективності завдяки забезпеченню належної уваги до інтересів споживачів, клієнтів, партнерів і навіть конкурентів; запровадження правил раціонального менеджменту та належного контролю.

Щодо зародження концепції соціальної відповідальності бізнесу Н. В. Марущак (2012) виокремлює низку етапів. Теоретичне підгрунтя концепції соціальної відповідальності бізнесу було закладене ще у XVIII ст., коли відбувалися індустріальні революції та формувалося сучасне уявлення про підприємництво. Власники окремих підприємств брали на себе відповідальність за своїх працівників, керуючись при цьому власними релігійними чи етичними переконаннями. На початку XX ст., відзначає науковець, у США зароджується доктрина капіталістичної благодійності, згідно якої прибуткові організації повинні жертвувати частиною своїх коштів на користь суспільства, тобто фінансувати суспільні потреби. Подальшого розвитку концепція соціальної відповідальності набула лише у 50-ті роки XX століття, зайнявши центральне місце у дискусії про відносини бізнесу та суспільства.

По іншому трактує еволюцію концепції соціальної відповідальності А. Колот (2013), котрий зауважує, що реакцією на потребу розбудови успішних прикладних систем соціально відповідальної діяльності стала поява в цій царині цілої низки концепцій, які містять результати наукового опрацювання питань соціальної відповідальності бізнес-структур. Наукова думка з цієї проблематики, на думку науковця, сконцентрована у таких концепціях: базова концепція (1950-1970-і роки); концепція корпоративної соціальної сприйнятливості (1970-1990-і роки); концепція корпоративної соціальної діяльності (1980-2000-і роки).

Безперечно, можливо виводити концептуальні засади соціальної відповідальності бізнесу від найдавніших часів, адже підприємництво та суспільство нерозривно пов'язані у своєму розвитку. Утім, вважаємо за доцільне користуватись хронологічними рамками розвитку концепції соціальної відповідальності, запропонованими у аналізованих працях, оскільки вони прив'язуються до основних етапів розвитку наукової думки 3 проблем менеджменту підприємств.

Слід зауважити, що окремі дослідники намагаються простежити більш давні свідчення зародження концепції соціальної відповідальності 
підприємств, утім ми погоджуємось 3 позицією Дєліні М. М. (2014), згідно з якою ця концепція зароджувалася як категорія регулювання соціальнотрудових відносин та отримала розвиток у вигляді благодійності спочатку американських багатіїв, а згодом й американських корпорацій. Науковець зазначає, що нині кількість форм їі прояву більш численна: це й захист навколишнього середовища, й впровадження новітніх засобів виробництва та управління, й всебічний соціальний захист працівника тощо.

Звичайно, у світлі відсутності єдиного підходу до побудови системи менеджменту соціальної відповідальності підприємств можливо виокремити незліченну кількість напрямків. Слід відзначити, водночас, що соціальна відповідальність як різновид управлінської діяльності $\epsilon$ досить складним явищем, що характеризується, передусім у вимірі витрат та часу i не передбачає однозначних здобутків для підприємства, що надає схожості цьому виду діяльності з благочинністю.

Утім, Брич В.Я. та Смачило I. I. (2014) звертають увагу на переваги, які надає для підприємства реалізація соціальної відповідальності: підвищення інвестиційної привабливості, збільшення обсягів продажу та прибутків, поліпшення процесів прийняття рішень та управління ризиками, оптимізація операційних процесів та зменшення виробничих витрат, зростання продуктивності та якості, ефективна база людських ресурсів, покращення репутації, більша лояльність покупців, поліпшення фінансових та економічних показників діяльності та інші.

3 іншого боку, Л.С. Селіверстова (2015) зауважує, що, як правило, корпоративна соціальна відповідальність підтверджується тільки «мінімальним набором» - вчасно сплаченими податками, регулярною

виплатою дивідендів, наданням соціального пакету та окремими благодійними заходами та акціями. Але як показують різноманітні дослідження в сфері корпоративної соціальної відповідальності, для того, щоб відповідати достатньо високим вимогам суспільства, необхідно грунтуватися не на окремих соціальних заходах, а цілеспрямовано вибудовувати комплексну політику підприємства в сфері корпоративної соціальної відповідальності.

Можливо виокремити й певний перелік чинників, котрі підштовхують до реалізації концепції соціальної відповідальності.

Д. Баюра (2009) до основних мотивів реалізації концепції соціальної відповідальності українськими підприємствами відносить такі, як розвиток персоналу компанії, що не лише запобігає плинності кадрів, але й дозволяє залучати кращих спеціалістів із ринку праці; потреба забезпечити зростання продуктивності праці в компанії; покращення іміджу компанії та зростання репутації; реклама товарів і послуг; висвітлення діяльності компанії в засобах масової інформації; стабільність і стійкий розвиток компанії в довгостроковій перспективі; можливість залучення інвестиційного капіталу для розвитку соціально-відповідальних компаній; збереження соціальної стабільності в суспільстві; в окремих країнах, в яких існують соціально відповідальні компанії, передбачені податкові пільги.

Важливим для соціальної відповідальності як загальносвітового руху $\epsilon$ стандартизація суміжних процесів.

$\begin{array}{lll}\text { Особливо значимим } & \text { здобутком } \\ \text { теорії та практики } & \text { соціальної } \\ \text { відповідальності та новим } & \text { етапом їх } \\ \text { розвитку слід вважати } & \text { прийнятTя } \\ \text { стандарту ISO 26000. Ю.В. Чала (2014) } \\ \text { зазначає, що цим } & \text { стандартом }\end{array}$


визначаються вказівки для керівництва про те, як підприємства та організації можуть працювати соціально відповідальним чином, що розуміють як дії в рамках етичних норм 3 метою внеску в здоров'я i благополуччя суспільства.

Щодо ситуації 3 реалізацією соціальної відповідальності в Україні, аналіз останніх досліджень засвідчує наступні закономірності.

Водночас, щодо ситуації в Україні 0. М. Головінов (2014) зауважує, що для українських компаній соціальна відповідальність переважно носить разовий характер, спрямований на покращення репутації, без бажання (часто і можливості) розглядати даний процес як тривалий i безперервний, нарешті, відсутня конструктивна, взаємовигідна взаємодія роботодавців і найманих працівників. Розвиток цього процесу в Україні має численні бар'єри, часом як штучні, так i природні. У національному господарстві України певною мірою представлені всі рівні реалізації концепції соціальної відповідальності. У той же час існуючу систему соціальної відповідальності неможливо назвати гармонійною, оскільки багато її елементів не виникли в ході еволюційного розвитку ринкових відносин, а залишилися у спадок від радянської системи соціального забезпечення.

Соціальна відповідальність у зв'язку зі своєю значимістю у довгостроковому вимірі відноситься до сфери стратегічного управління підприємствами. Як зазначає Стойка B.0. (2014), у сучасних умовах господарювання соціальна відповідальність бізнесу $\epsilon$ складовою його корпоративної стратегії. 3 позиції юриспруденції, реалізація принципу соціальної відповідальності пов'язана 3 публічно-правовим регулюванням фондів грошових коштів комерційних організацій, тобто правове регулювання відносин щодо розподілу прибутку повинно забезпечувати використання частини прибутку комерційних організацій 3 метою здійснення соціальної функції і часткового фінансування програм із вирішення соціальних проблем суспільства.

Щодо заходів, які включаються до концепції соціальної відповідальності, погодимося $з$ Д. Баюрою (2009), котрий відзначає, що розвиток економіки України та системи корпоративного управління на основі відповідальності та якості зумовлює актуальність проблеми формування корпоративної соціальної відповідальності підприємств. 3 цього приводу, як зауважує науковець, ООН та міжнародне співтовариство вдаються до заходів, які спрямовані на розвиток партнерства між державою та бізнесом, роботодавцями та працівниками i грунтуються на правах людини. Проведений науковцем аналіз діяльності соціально-відповідальних компаній України засвідчив найбільш вираженість таких напрямів їх соціальної активності: підтримка соціально незахищених верств населення, розвиток соціальної інфраструктури, розвиток освіти, спонсорська допомога, молодіжні програми, надання медичних i рекреаційних послуг своїм працівникам тощо.

Щодо соціальної відповідальності підприємств перед територіальними громадами в Україні Н.М. Градюк (2011) відзначає, що більшість великих вітчизняних компаній вважає свою участь у розвитку територіальної громади складовою власної стратегії корпоративної соціальної відповідальності. Представники цих компаній позиціонують свою діяльність, спрямовану на вирішення тих чи інших соціальних проблем територіальної громади та суспільства, саме як вагому складову політики соціальної корпоративної відповідальності компанії. При цьому, наголошує 
науковець, мова не йде про те, що корпоративна благодійність $\epsilon$ повноцінним виявом соціальної відповідальності перед громадою. Навпаки, пов'язуючи ї̈ з власною місією, стратегією та ключовими компетенціями, компанії інтегрують благодійність та участь у життєдіяльності громади в загальні стратегії розвитку бізнесу, що охоплюють широке коло завдань та відповідальностей компанії.

Дєліні М. М. (2014) відзначає, що, у зв'язку 3 тим, що соціальна відповідальність бізнесу $\epsilon$ сьогодні загальновизнаним правилом, якого дотримується значна кількість великих, середніх і навіть малих підприємств різних країн світу, питання їі розвитку належать до сфери особливої уваги органів державної влади та провідних міжнародних організацій. Проявом цієї уваги, на думку Дєліні М. М. $\epsilon$ розроблення стандартів і заходів зі стимулювання організацій до соціально відповідальної діяльності. У більшості країн ЄС у різній формі розроблені та функціонують державні програми ㄲï підтримки і стимулювання. Такі інституційні заходи спрямовують бізнес на дотримання певних правил поведінки, заохочують державні та приватні організації до спільного виконання соціально важливих завдань, матеріально стимулюють бізнес до соціально відповідальної діяльності. На жаль, наголошує Дєліні М. М., формування інституційної підтримки соціальної відповідальності в Україні перебуває в стадії становлення. Автоматичне впровадження концепції соціальної відповідальності неможливе, тому, що надмірна «зарегульованість» економіки з боку держави у вигляді високих податків і соціальних трансфертів здатна привести до зниження мотивації до праці i інвестиційної активності, можливе переміщення виробничої діяльності 3 легальної області в нелегальну.

\section{ВИСНОВКИ}

Таким чином, на основі проведеного дослідження встановлено, що соціальна відповідальність $є \quad$ синтетичною категорією, що пройшла тривалий розвиток, доповнюючись новими елементами відповідно етапів розвитку теорії менеджменту. На сучасному етапі концепція соціальної відповідальності підприємств підтримується на міжнародному рівні ООН та урядами держав, поділяється найбільшими підприємствами і вважається однією 3 запорук сталого розвитку економіки. Водночас, в Україні концепція соціальної відповідальності набула особливих регіональних обрисів, що пов'язується 3 кризовими явищами в економіці та суспільстві. У підсумку це обумовило відсутність єдиної державної політики соціальної відповідальності бізнесу, несистемність заходів підприємств 3 реалізації основних положень, відсутність системного підходу щодо трансформації менеджменту соціальної відповідальності.

Перспективним напрямком подальших досліджень $\epsilon$ напрацювання принципів та методів менеджменту соціальної відповідальності підприємств.

\section{References}

Baiura, D. (2009). Korporatyvna sotsialna vidpovidalnist $\mathrm{u}$ systemi korporatyvnoho upravlinnia. Ukraina: aspekty pratsi, 1. 21-25

Brych, V., \& Ya. Smachylo, I. I. (2014). Sotsialna vidpovidalnist vitchyznianykh pidpryiemstv. Tekhnolohycheskyi audyt $y$ rezervы proyzvodstva, 5(2). 36-39

Chala, Yu. V. (2014). Sotsialna vidpovidalnist pidpryiemstv yak osnova innovatsiinoho rozvytku suchasnoi ekonomiky. Problemy $i$ perspektyvy rozvytku bankivskoi systemy Ukrainy, 40. 275-285 
Dielini, M. M. (2014). Problemy vprovadzhennia korporatyvnoi sotsialnoi vidpovidalnosti. Visnyk Odeskoho natsionalnoho universytetu. Seriia: Ekonomika. T. 19, Vyp. 2(5). 38-41.

Holovinov, O. M. (2014). Sotsialna vidpovidalnist biznesu: ukrainski realii i problemy. Ekonomichnyi visnyk Donbasu, 2. 187-192

Hradiuk, N. M. (2011). Sotsialna vidpovidalnist pidpryiemstv $\mathrm{v}$ umovakh stanovlennia hromadianskoho suspilstva $\mathrm{v}$ Ukraini. Rehionalna ekonomika, 2. 143-150

Kolot, A. M. (2013). Korporatyvna sotsialna vidpovidalnist: evoliutsiia ta rozvytok teoretychnykh pohliadiv. Ekonomichna teoriia, 4. 5-26
Lazorenko, L. V. (2013). Korporatyvna sotsialna vidpovidalnist yak innovatsiina stratehiia biznesu. Visnyk Skhidnoievropeiskoho universytetu ekonomiky i menedzhmentu. Ser.: Ekonomika i menedzhment, 1. 89-96

Marushchak, N. V. (2012). Evoliutsiia kontseptsii korporatyvnoi sotsialnoi vidpovidalnosti. Yevropeiski perspektyvy, 2(1). 213-221

Seliverstova, L. (2015). Formuvannia stratehii korporatyvnoi sotsialnoi vidpovidalnosti. Aktualni problemy ekonomiky, 7. 309-314

Stoika, V. O. (2014). Sotsialna vidpovidalnist biznesu - vazhlyva skladova ahroprodovolchoho rynku. Ekonomika kharchovoi promyslovosti, 4. 79-84 


\section{Global Prosperity Volume 1 Issue 1 2021}

Date of Issue: 2021 April, 25

All journal content is licensed under a Creative Commons BY 4.0 International license 